Historic, Archive Document

Do not assume content reflects current scientific knowledge, policies, or practices. 


\section{Home Beautifying Suggestions}

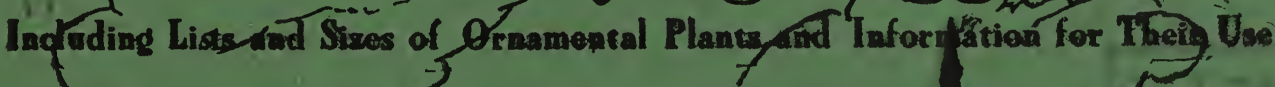

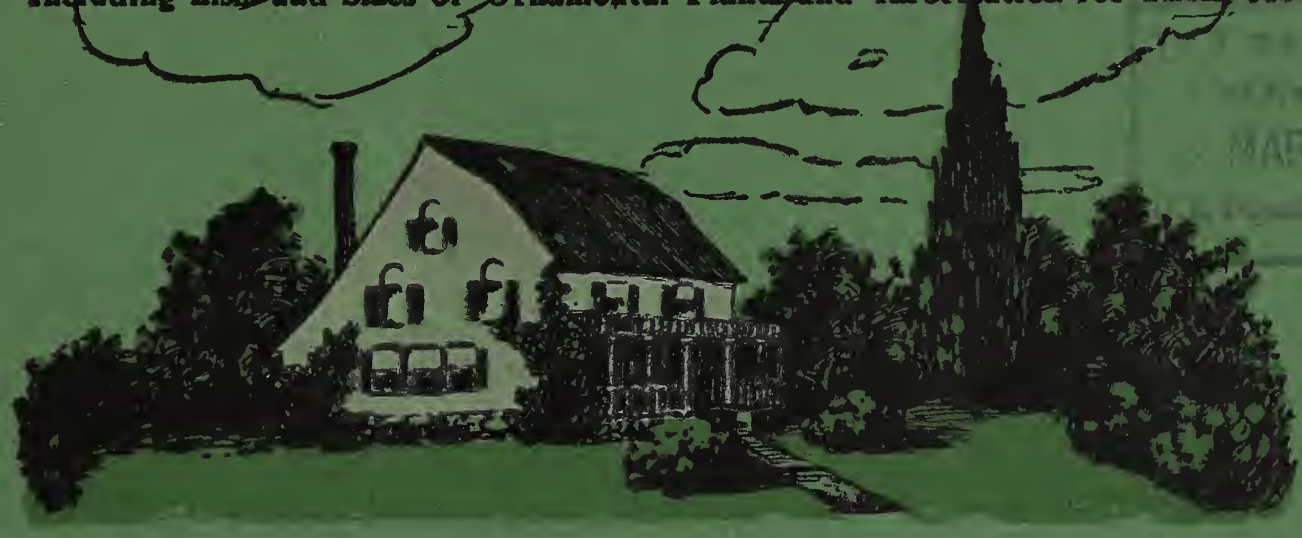

William C. Moore \& Co., Newark, N. Y. 
$\sqrt{2}+$
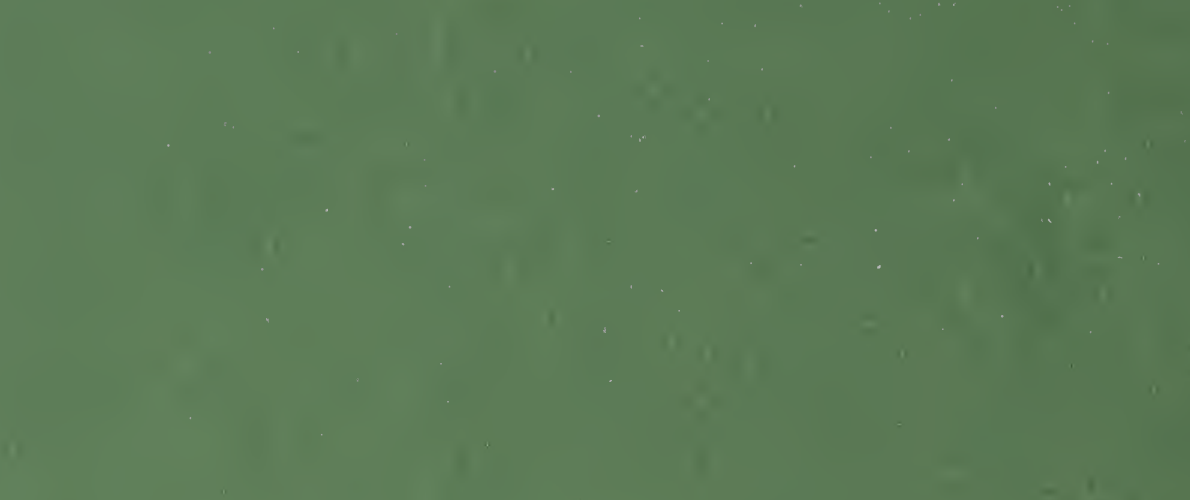

$$
=0
$$

, 8
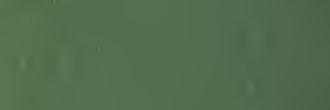

$7 x$

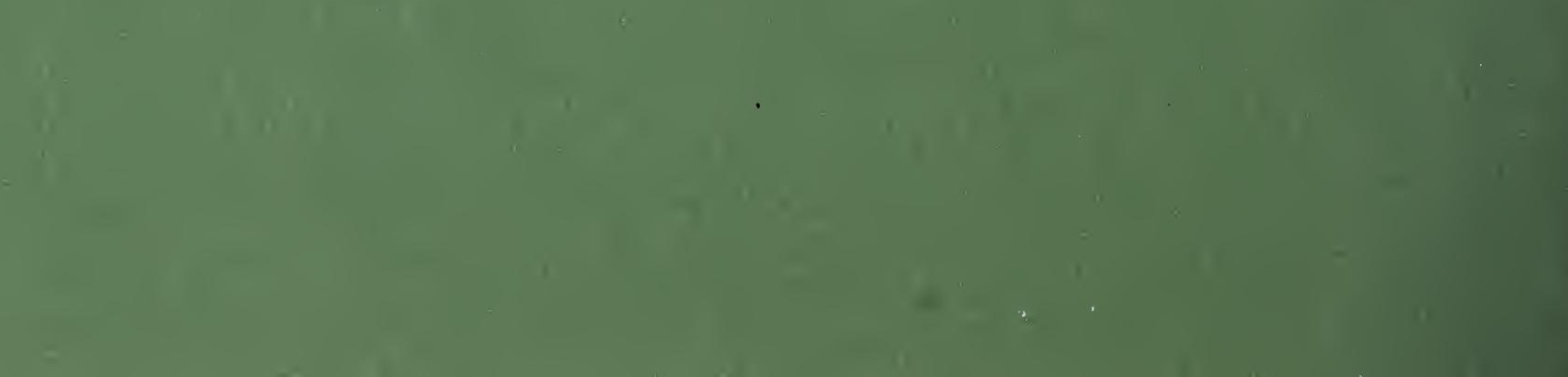




\section{HOME BEAUTIFYING SUGGESTIONS Including Lists of Hardy Ornamental Stock and Information for Their Proper Use}

HIS little booklet is put out to assist our customers in arriving at a decision as to what they want to plant in their grounds. It is hard to judge by the catalogue description as to how these shrubs will look in connection with the different style houses. We hope that the planting list placed at the side of the result will be a great assistance in doing this.

The engravings have been made from photographs that were taken of cheap or moderate priced homes, such as the majority of us must be satisfied with, and which respond to horticultural planting even more effectively than the more elaborate huuses which have special architectural beauties of their own that can best be set off by experienced landscape gardeners. Even books upon landscape gardening are written by those whose experience runs to the large plantings, and their suggestions and plans are too large for the average home owner.

The principles of proper planting are not hard to master. The shrubs should be massed into corners and borders, and a selection made differing in height so that all of them can be seen and intermingle in effect, with their bloom coming at different seasons so that they are 
always interesting. You can easily choose this graduation from the lists referred to. Specimen trees or shrubs should be planted sparingly, and with plenty of "elbow room" so that their beauty can be fully appreciated.

When shrubs get old and become unsightly or course they should be grubbed out and replaced by new ones of slender willowy growth. The modern practice is to allow about three feet for each shrub. The tendency is to crowd the shrubs for a denser, more pleasing effect. They will thrive just as well but require pruning from time to time. Landscape gardeners are generally planting a border of summer flowering perennials in front of each planting of shrubs to cover their stems, and also to carry the color attraction after the shrub itself has lost its flowers. The perennial that was once grown "in the flower garden" is now a legitimate part of every landscape planting.

One may have an "elegant house" but it is impossible to have a Beautiful Home that is not surrounded in some degree with the verdure of nature. No matter how substantial or how costly, no building is complete until it is set in a frame of God's own making. Many an old and unsightly building is made beautiful by the trees and foliage with which it is surrounded.

No other investment possible for a man to make will bring the pleasure that will spring into his heart at the sight of his home surrounded with lovely shrubs and trees, and in addition to its dividends of satisfaction such plantings have an economic value of as great proportion. Your new house may be all that you can ask for, the niftiest on the street, but you must know that in a few years nicer and newer ones will overshadow it. If you let nature help you, you need fear no rivals. The newcomers must wait until they can grow surround- 
ings as lovely as yours to catch up with you. A house buried in the splendor of shrubs, trees and flowers will always sell at a big percentage above the same house unadorned, it will even rent higher, and it is no longer a novelty to find the landlord looking for a tenant extolling this feature of his premises. Every season you let planting go by is a loss.

There are many fruit trees that give as good decorative effects in the garden as purely ornamental trees, and we have a complete selection of all the leading varieties for this planting from which plantings can be made and will send our regular catalogue upon request.

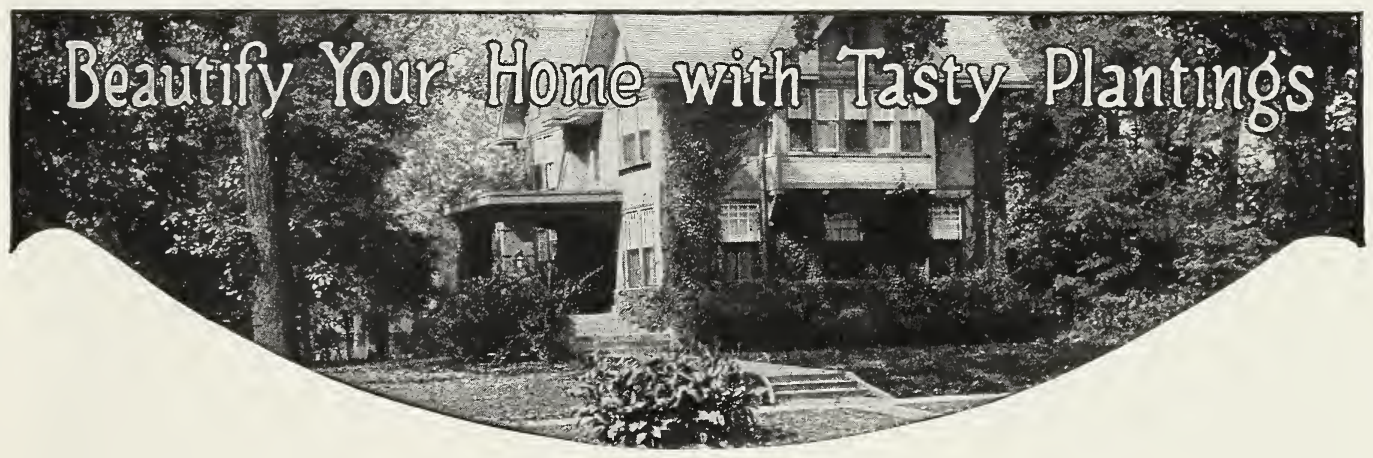




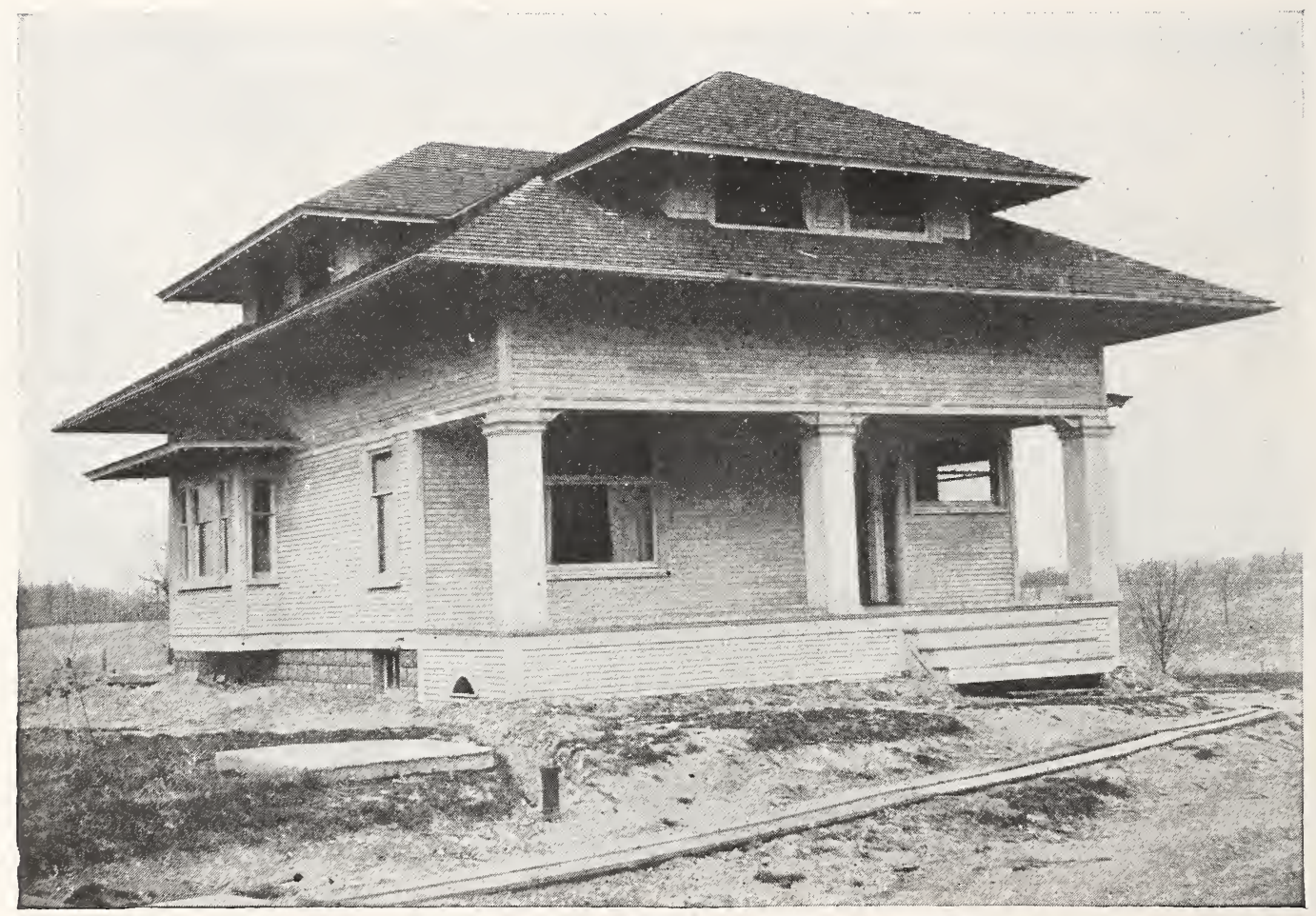

Is planting worth while? A house with no trees to shelter it or shrubs to clothe it. See the following picture. 


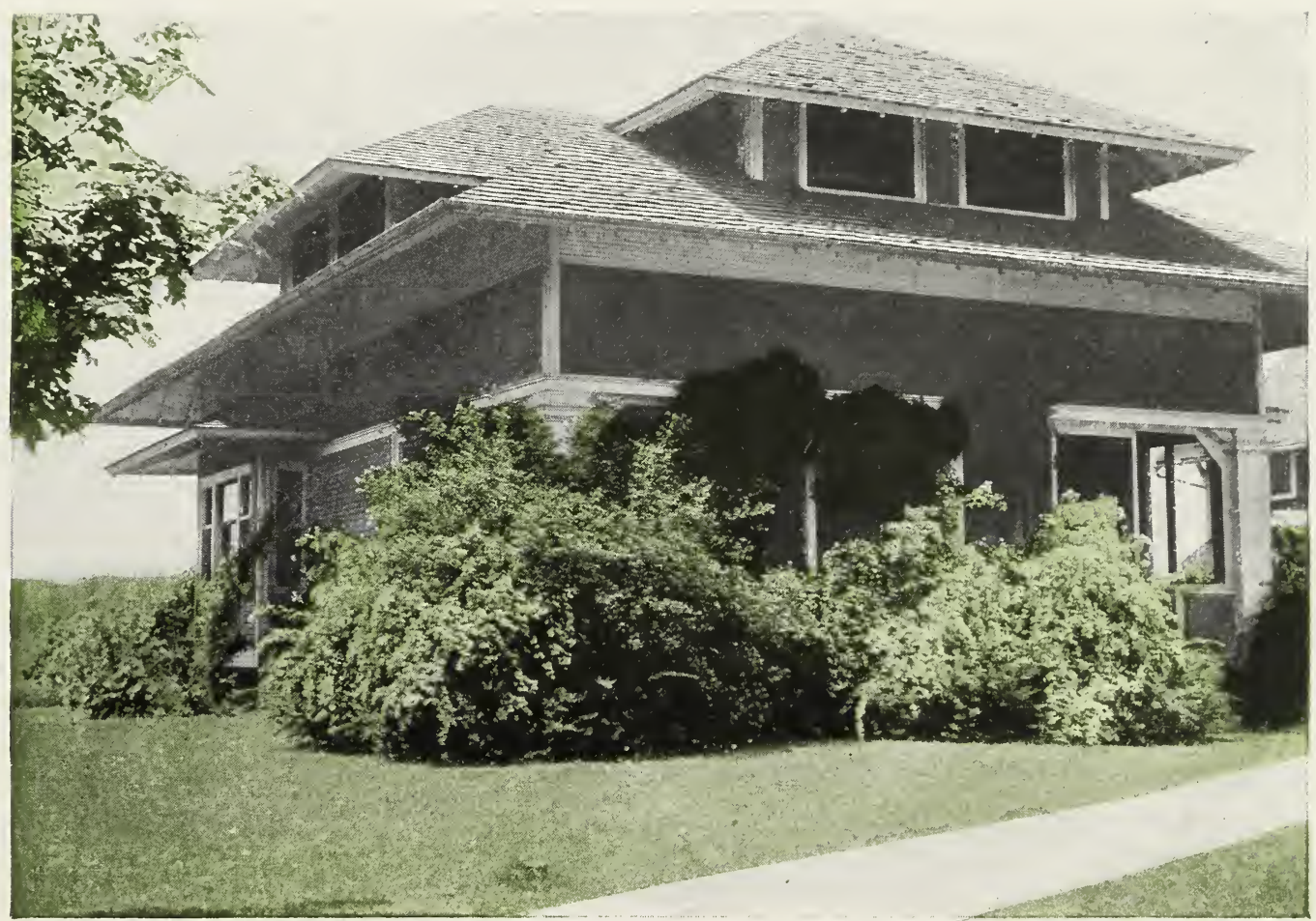

Same place as preceding picture-but about three years later. Was planting worth while? 


\section{For the Village and Farm}

\section{A Simple and Beautiful Planting}

The planting shown here is especially adapted to homes placed well back from the street and ample width to set it off with a fair lawn. Elaborate plantings are not necessary in order to make a greatly improved appearance to the home and this picture is the best evidence of it you could get.

The porch group on the left hand side consists of only three Sarberry Thunbergii (2); six Spirea Thunbergii (3) (3); six Hydrangea Paniculata Grandiflora (4) (4); two Boston Ivy (5) (5). This planting is almost complete in itself.

The right hand side of this planting consists of only nine Barberry Thunbergii (1) (1), on account of a broad walk extending next the porch. In case there is no side entrance, the doubling of the left hand group would make a symetrical and beautiful planting.

\section{PLANTING LIST}

No. 1. Nine Barberry Thunbergii.

No. 2. Three Barberry Thunbergii.

No. 3. Six Spira Thunbergii.

No. 4. Six Hydrangea Paniculata Grandifiora.

No. 5. Two Boston Ivy.

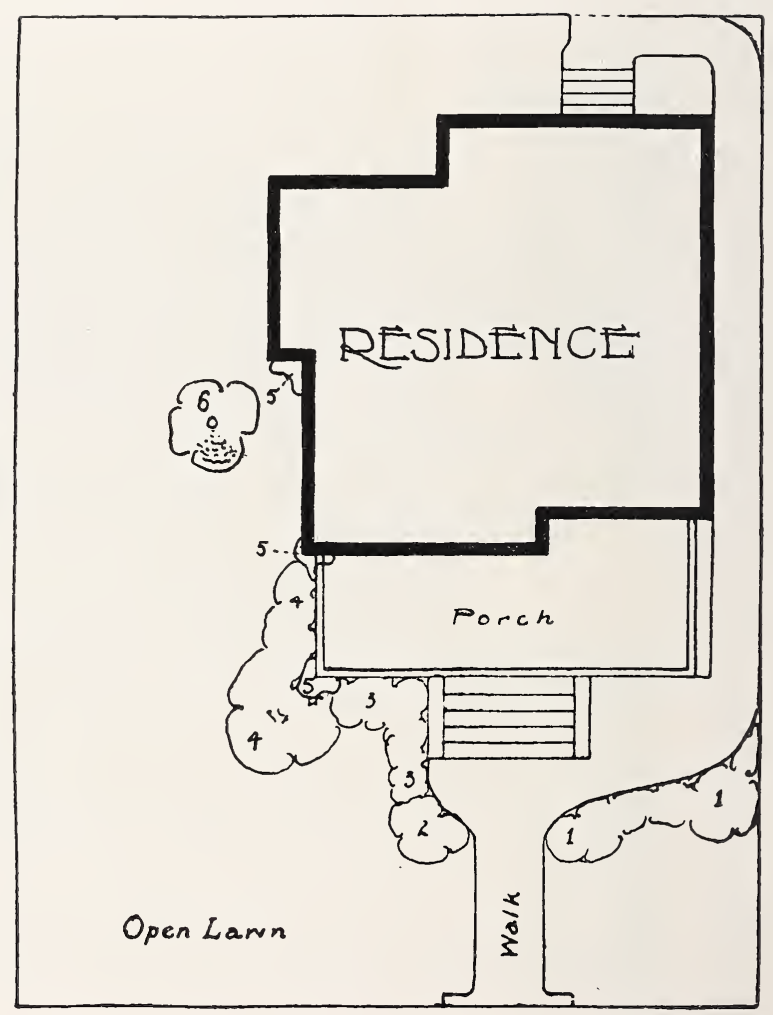




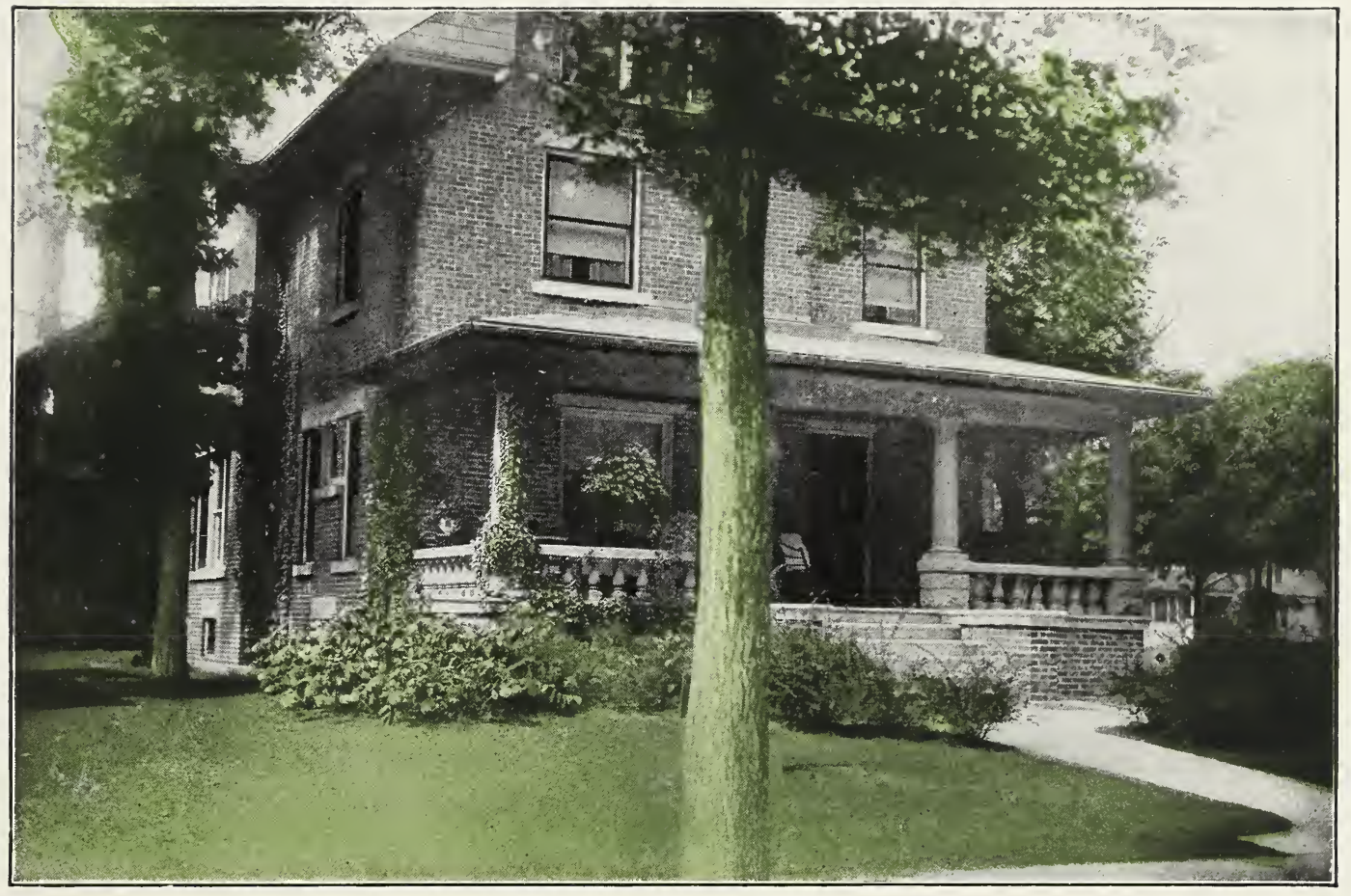




\section{A NICE CITY HOME With Inexpensive Planting}

This style of pianting for a city residential street is within the means of anyone, adds greatly to the value of the property, and the cost is very low. See what we can do for you.

The porch, which is the out door home of the family dur. ing the summer, is also the chief point of interest when properly planted as this one is, with sixteen Thunbergii Barberry at (2) and (5), two Hydrangea P. (G. at the steps' ends (3) (4), a Spirea Thunbergii at (6) and a Spirea Van Houttei at (7), with a Scarlet Trumpet Honeysuckle or Clematis Pani. culata for afternoon shade (1).

On the left side is shown a lawn background corner that is available very many places, a Persian Lilac or a Smoke Tree at (7), surrounded by four Hydrangea P. G. grouped in front at (10). This makes a splendid combination because the Lilac or Smoke Tree will bloom early in the summer and the Hydrangea about the last flower of the fall.

On the right hand side of the house the Gardener has placed an interesting group of Persian Lilac and three Spirea Van Houttei (9).

A bed of Funkia, Day Lilies, are often used for a narrow foundation covering as indicated at (11) where shrubs would grow too large. These can be furnished in sufficient quantity to make a good bed the second year.

PLANTING LIST-No. 1. One Scarlet Trumpet Honeysuckle; No. 2. Seven Barberry, Thunbergii; No. 3. One Hydrangea P. G.: No. 4. Three Hydrangea P. G.; No. 5. Nine Barberrz Thunbergii; No. 6. One Spirea Thunbergii; No. 7. One Spirea Van Houttei ; No. 8. One Persian Lilac; No. 9. Three Spirea Van Houttei; No. 10. Four Hydrangea P. G.; No. 11. Bed of Funkia, Day Lilies; No. 12. American Elm; No. 13. Cherry; No. 14. Fence covered with vines: Ampelopsis Englemann's Ivy, Honeysuckle Scarlet Trumpet, Honeysuckle Hall's Japan; No. 15. Silver Maple.

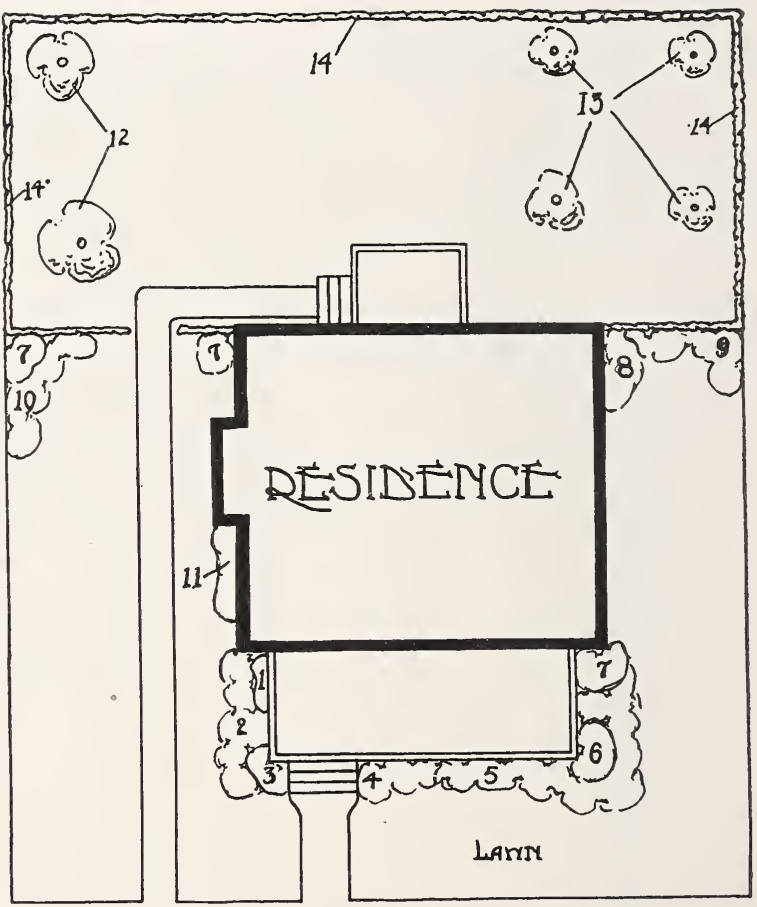

YALK

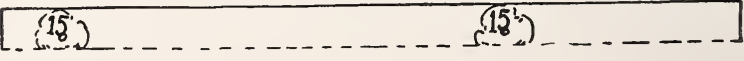




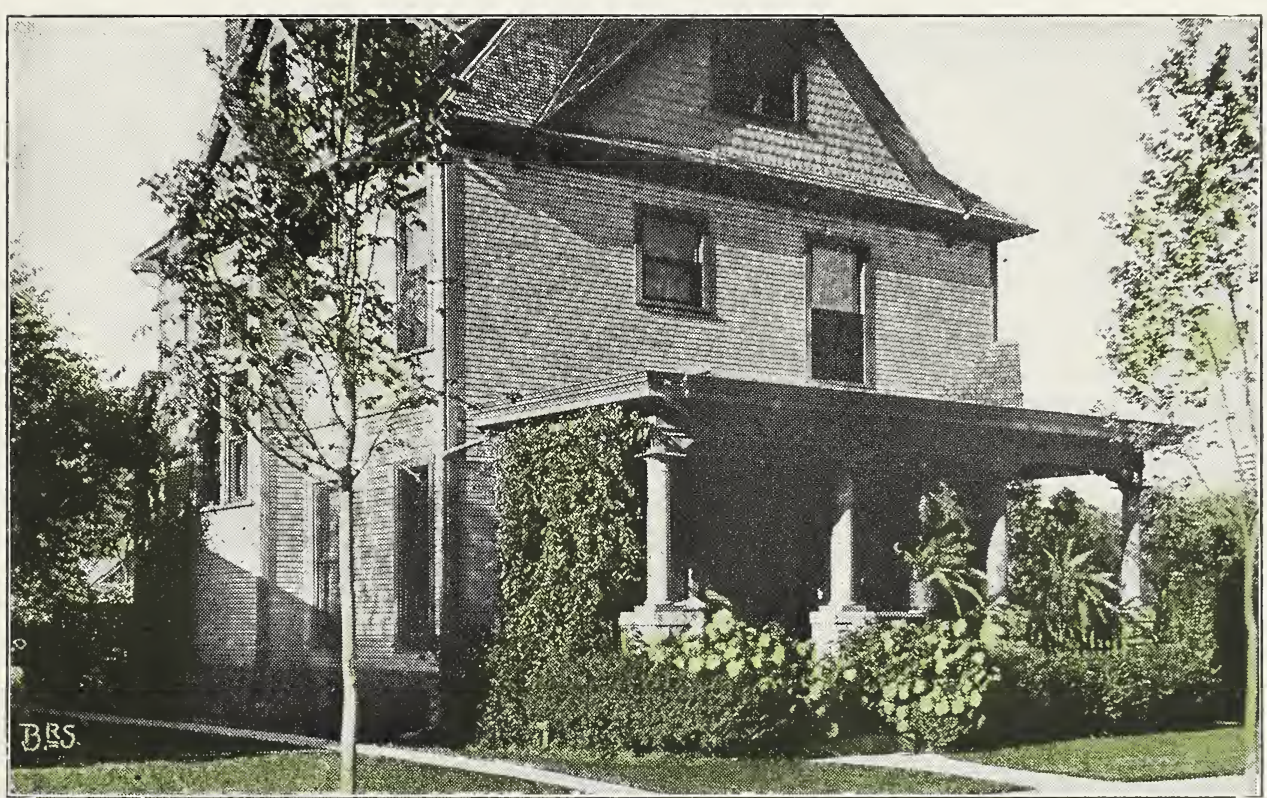




\section{A LOVELY HOME}

\section{On a Small Lot}

The landscape gardener in designing this plan, planted twelve Spirea Van Houttei (2) (2) along foundation of the front porch. If you did not care for the ear.y bloom of white, Rosa Rugosa or Snowberry would prove interesting and effective at about the same cost.

Boston Ivy or Englemann's Ivy, which has a smaller leaf and more dense foliage is a very desirable addition to Stucco or cement houses. Two were used here (1).

The clump of ten Clethra (Sweet Pepper Bush) each side of the walk is a delightful little group of shrubs. For bungalows and one-story places a similar group of Deutzias (Lemoine or Gracillis) would be available at the same price.

Along the side of the entrance steps there was planted five Indian Currants, a low shrub that is easy to keep within bounds.

- The Specimen Tea's Weeping Mulberry is used here with splendid effect, and is largely planted. The five specimen trees (6) are largely a matter of individual choice, and the reader is referred to the brief descriptions of suitable ones from the list at the back of the booklet, taking care to select those which will not too quickly overrun the space assigned tni'm.

PLANTING LIST-No. 1 'T'wo Linglemann's Ivy on house; No. 2. Twelve Spirea V. H.; No. 3. Five Coral Berry; No. 4. Ten Pepper Bush (beds in front); No. 5. One Tea's Weeping Mulberry (specimen); No. 6. Specimen tree

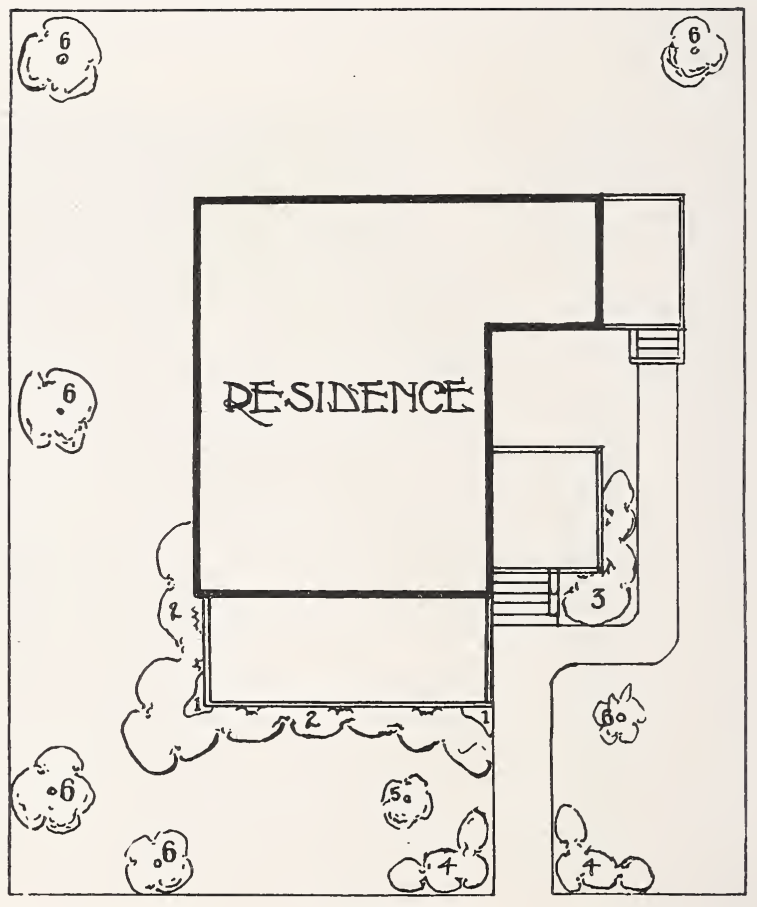

WALK 


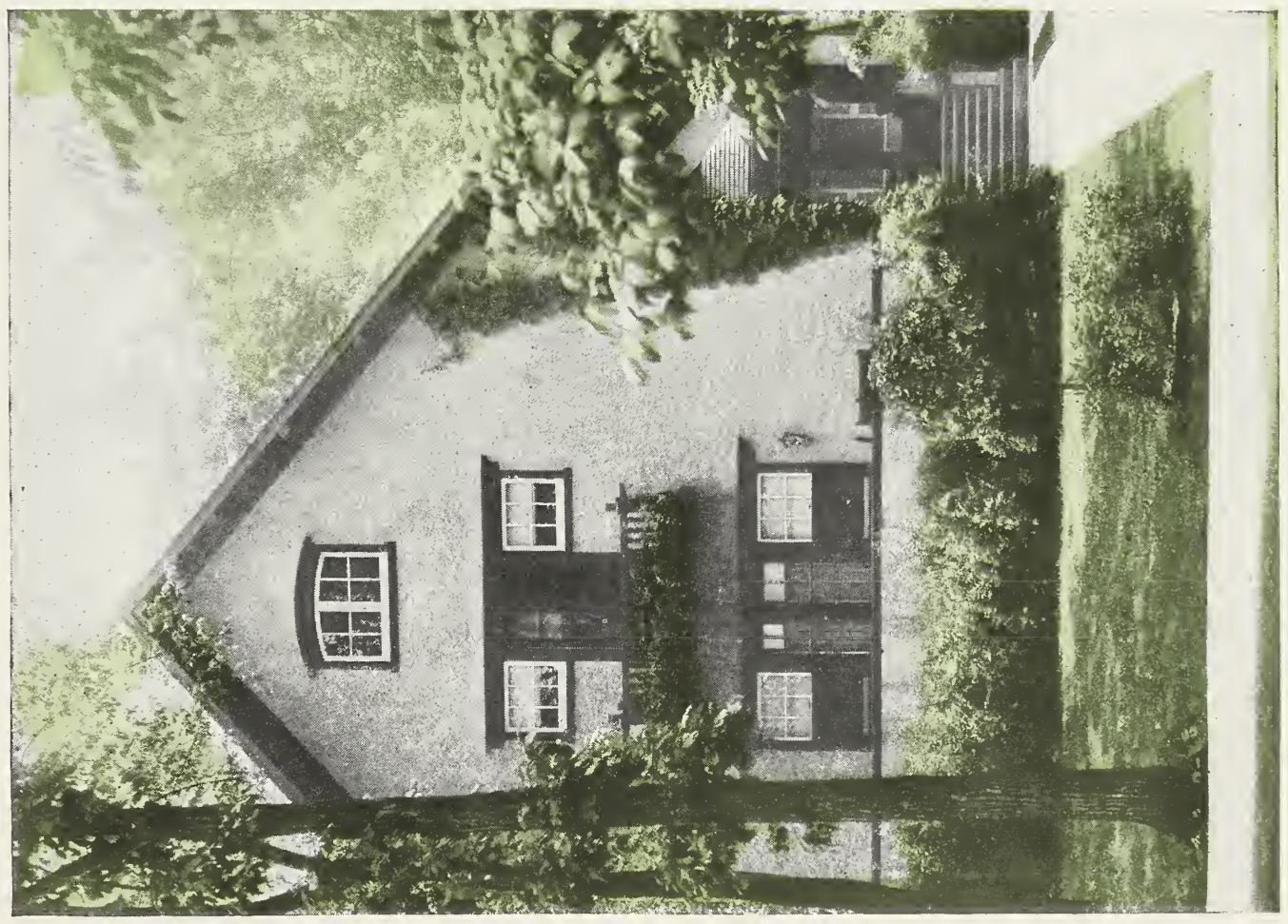




\section{An Old Fashioned Home}

\section{Still Modern and Attractive}

This planting list aptly shows the joys and pleasure one can derive from Nature. Without a setting of trees and shrubs a house is merely such, but with proper planting, no matter how humble the place, everyone knows that it is a home.

This old-fashioned house was surrounded by a couple of beds of perennials (4) which probably antidate the shrubbery but is a feature worth building at any time.

The porch is screened in at the end with the useful Aristolocia, or Dutchman's Pipe, with its large closely interwoven leaves at (1) and Boston Ivy is seen at (2).

The dominant flower that was in bloom when the photo was taken is the Arboresens Hydrangea at (3), which makes \& low growing shrub of great beauty in bloom.

Buddleia or Butterfly Bush, Calycanthus, Ribes, the Flow. ering Currants or some of Spirea families are recommended for massing along the walk at (5), while along the walk running in front of the main part of the house at (7) is screened by Barberry Thunbergii. The specimen trees are indicated by (8) (9) of which rather too many were planted. and a Tea's Weeping Mulberry at (11). Hall's Japanese Honeysuckle is suggested as a very desirable vine for the screening of back fences and alleyways.

PLANTING LIST-No. 1. Aristolocia or Dutchman's Pipe. No. 2. Boston Ivy; No. 3. Hydrangea Arboresens; No. 4. Perennial bed of Phlox, Delphinum, Iris and Shasta Davies; No. 5. Buddleia. Calvcanthus and Ribes; No. 6. Iberis or Candy Tuft border; No. 7. Barberry Thunbergii; Nos. 8, 9. Specimen trees; No. 10. Japanese Honeysuckle; No. 11. Tea's Weeping Mulberry.

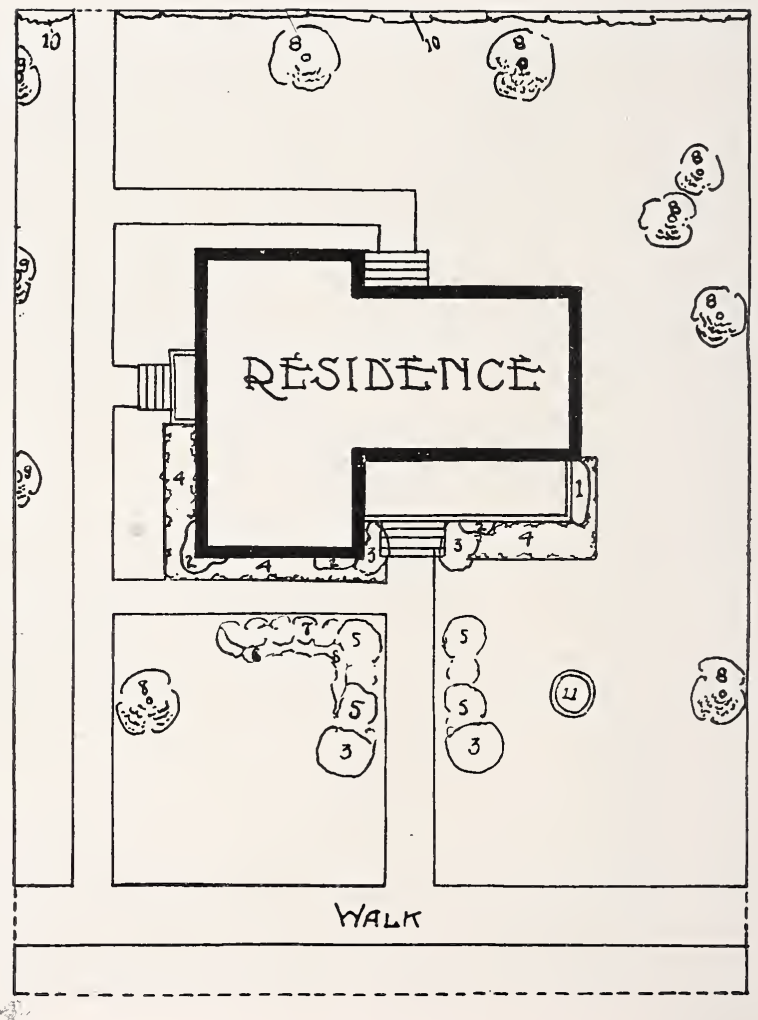




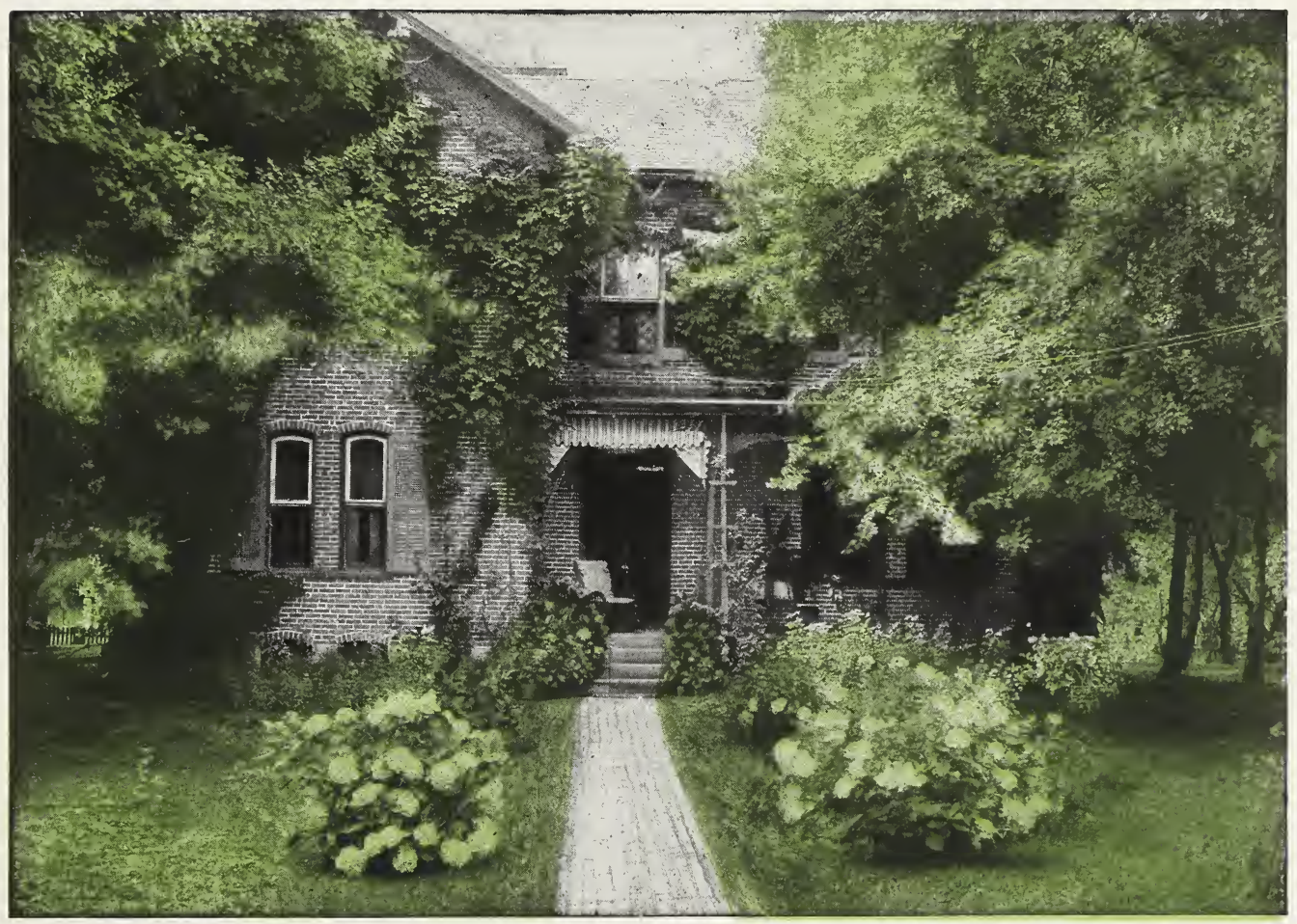




\section{A COLONIAL HOUSE Made Modern}

This house may have been built a hundred years ago-it does not matter as to the style of architecture used, each and every one can be made more beautiful by the proper ornamental planting.

To the right of the entrance of the Colonial house is a very pleasing combination of plants that could be used to good advantage in many places. At (9) three Buddleia But terfly Bushes have been placed. This plant has a beautiful lilac-like blooin from July to September. At (10) are six Lemoine's Deutzia, a shrub with white flower panicles; six Spirea Van Houttei are placed at the corner (11). This is one of the most beautiful shrubs and very largely grown. Near the corner of the house (12) is a Clematis, Jackmanni, an attractive vine with brilliant flowers.

To the left of the entrance the designer of this planting has placed three Buddleia Butterfly Bushes (1), six Lemoine's Deutzia (2), sevien Lemoine's Deutzia (3). Three of the fragrant blooming Common Lilacs are placed in the recess made by the sun parlor (4).

The attractive Purple Fringe or Smoke Tree (5) makes a beautiful central point of interest to the planting. Seven Japanese Barberries, a shrub which is very extensively used in landscape work, are planted at (6). The back corner plant. ing is formed with five Spirea Van Houttei (7), and five Iris and five Hardy Phlox at (8).

PLANTING LIST-No. 1. Three Buddleia (Butterfly Bush). No. 2. Six Deutzia, Lemoine's; No. 3. Seven Lemoine's Deutzia; No. 4. Tree Lilacs, Common; No. 5. One Smoke Tree; No. 6. Seven Japanese Barberry; No. 7. Five Iris, five Phlox; No. 9. Three Buddleia (Butterfly Bush); No. 10. Six Deutzia, Lemoine's; No. 11. Six Spirea Van Houttei : No. 12. Clematis Jackmanni; No. 13. Two Specimen Trees.

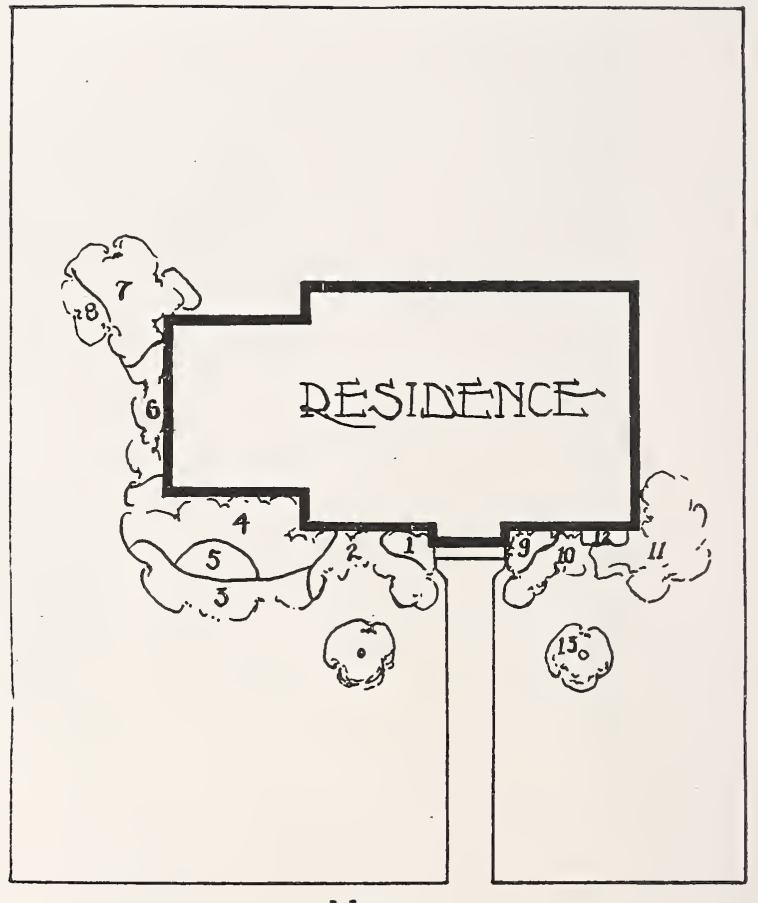

KALK 


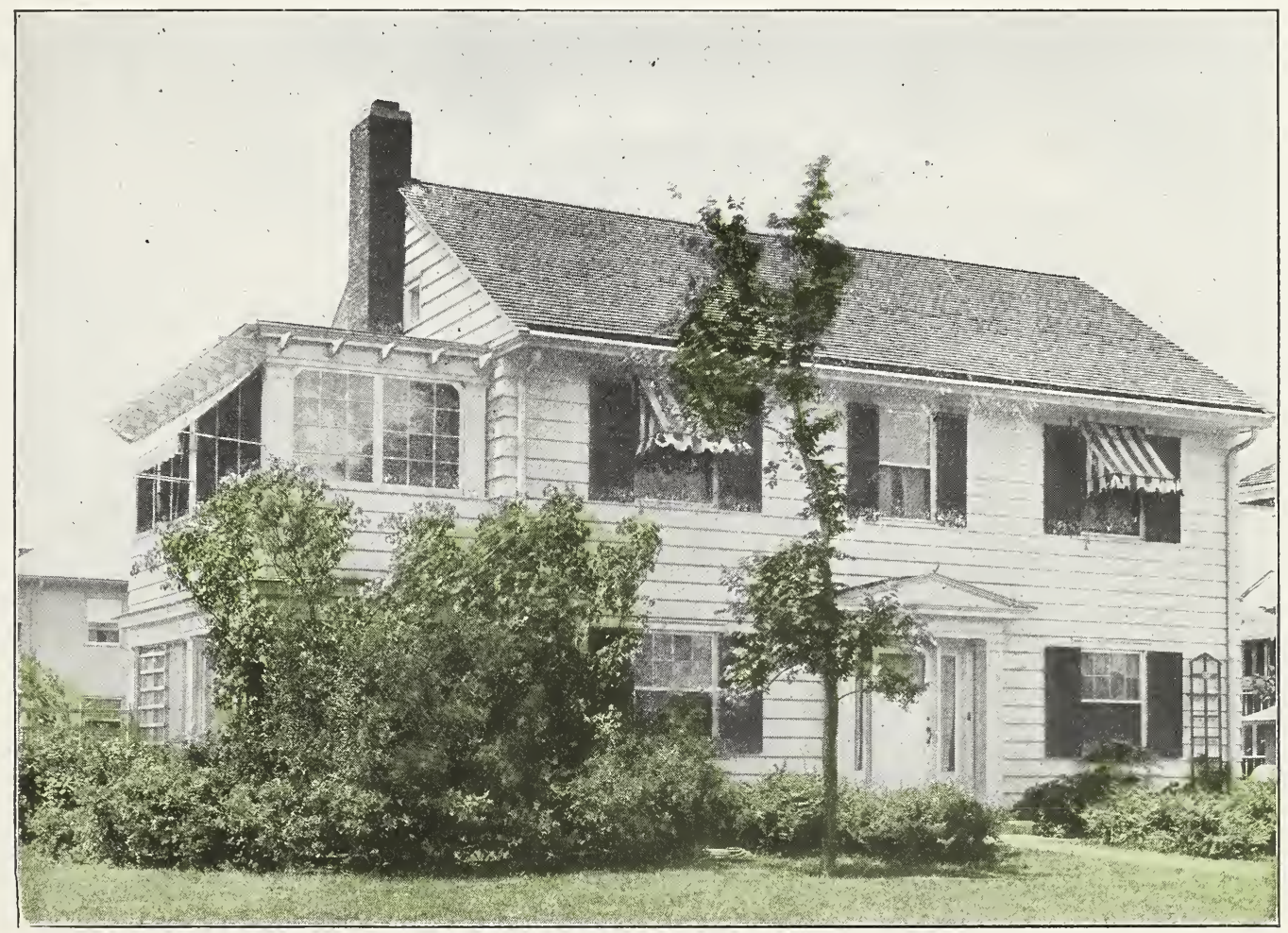




\section{A SUBURBAN DELIGHT}

\section{Shrubs Make Fine Homes}

No matter what the architectural plan of the house is, it is bare, cold and hardly suited for habitation in the good old summer time until adorned with shrubs. This place shows well the advantage of mass planting.

This foundation planting has a succession of blooms from April to July. At each end of the steps (1) the landscape gardener has placed a Forsythia, Fortune's Golden Bell, one of the earliest of shrubs to bloom when in April it is covered with golden bell-like flowers before the leaves appear. The base of these is covered with Barberry Thunbergii (2). The Tamarisk (4) shows forth its pink feathery flowers from May to July. A very handsome and decorative shrub, the Rhodotypus, White Kerria, has been planted at the corner of the house (5). In May and June its delicate white flowers bloom and are followed by shining black fruit which stays throughout the fall. At (3) has been planted Eva Rathke Weigelias which with their beautiful foliage and deep crimson flowers in June and July add much to the planting.

PLANTING IIST-No. 1. Forsythia, Fortune's Golden Bell; No. 2. Barberry Thunbergii; No. 3. Weigelia, Eva Rathke; No. 4. Tamarix Gallica; No. 5. Rhodotypos, White Kerria; No. 6. Caragana, Pea Shrub; No. 7. Iris, Japanese and German; No. 8. Hybrid Perpetual Roses; No. 9. American Elm: No. 10. Norway Maple.

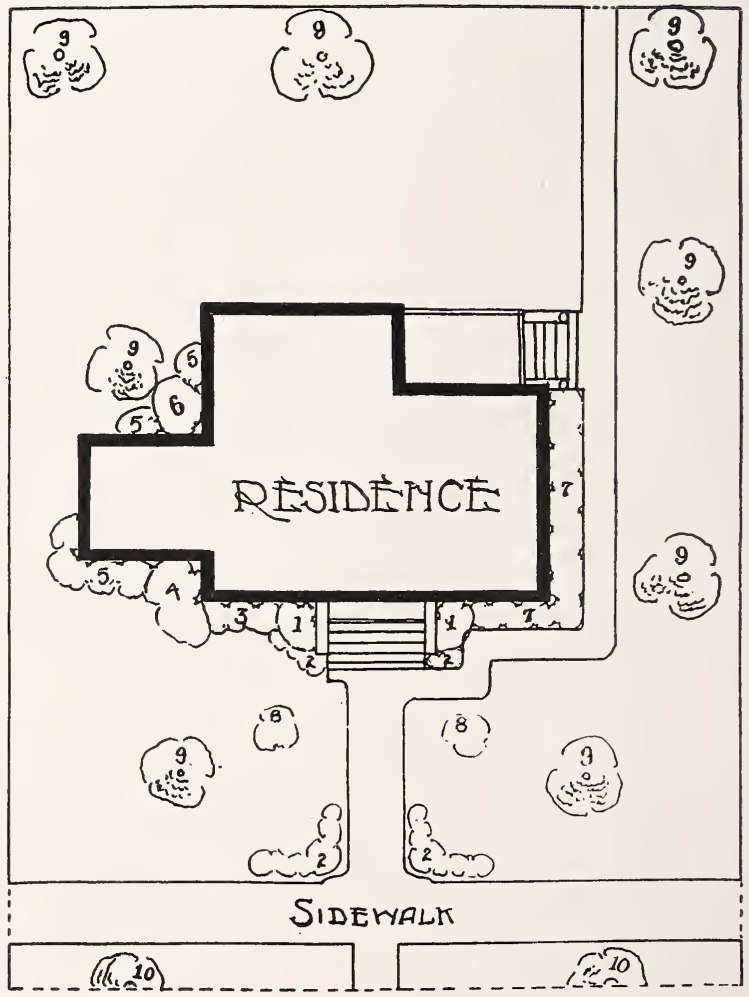




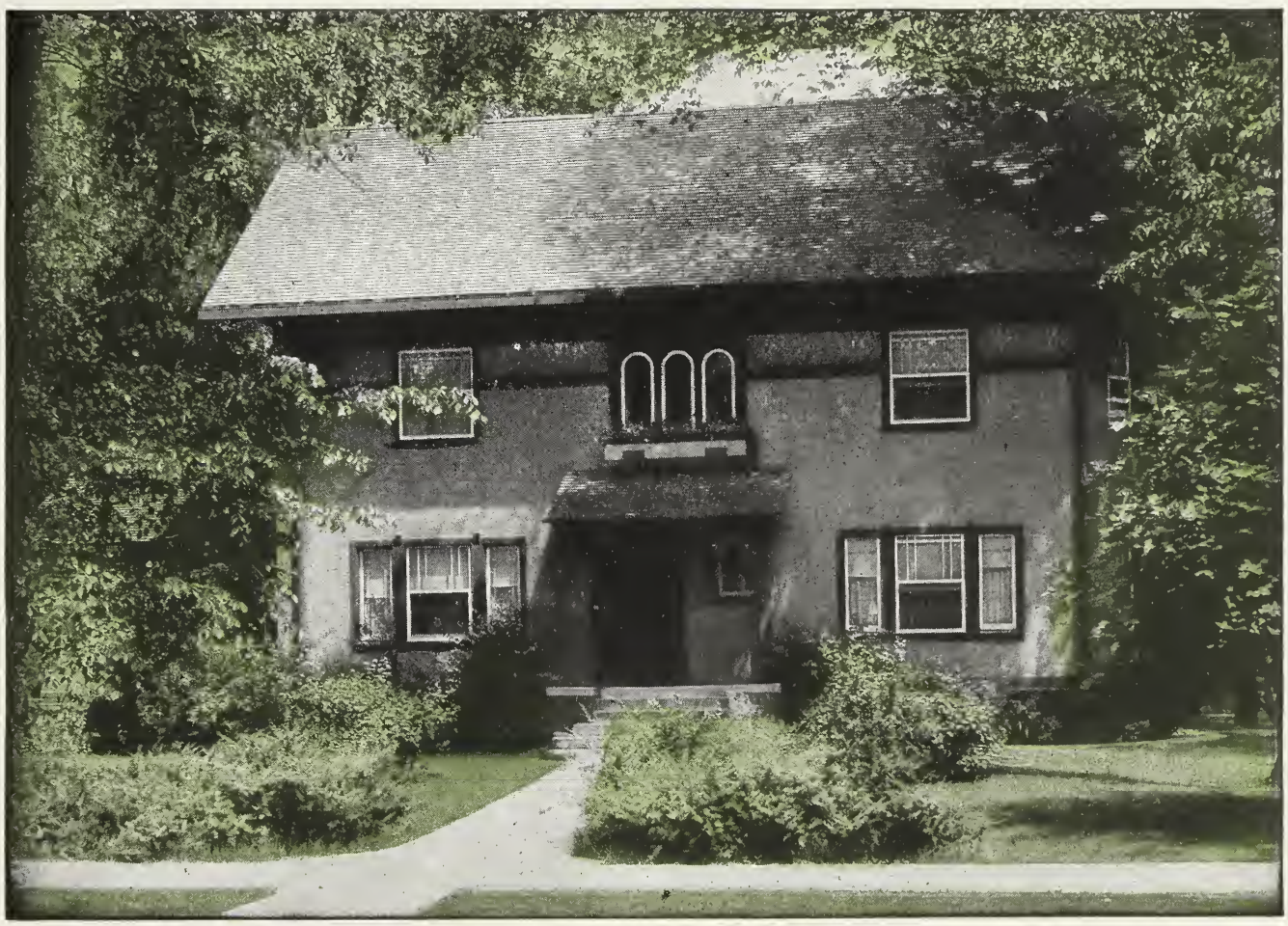




\section{A Bungalow Adorned The Value of Mass Planting}

Although this bungalow is well massed in shrubbery which fully doubles its pleasure value, the planting is comparatively simple.

The foundation planting around the front of the plazza is a row of five Spirea Van Houttei with four more for the corner mass. If the walls are brick two Boston Ivy as shown in the picture will add much to the effect.

At the street the landscape gardener has planted a Japanese Barberry hedge (5), eighteen inches apart, and a clump of five Snowberries or Indian Currants at the entrance walk (6).

On the right hand side of the entrance two clumps of the Snowberry (6) are used, with the Barberry hedge connecting them.

To make a good division clump on a narrow strip of lawn the design at the right of the house is a good one. Two Roses of Sharon (4) are met by a group of eight Indian Currants.

For the corner ornament to the extreme left the designer of the planting placed a group of five Rhodotypos or White Kerria (8) supported on the right by the Barberry and back slong the line with a very interesting group of five Tamarix.

PIANTING IIST-Foundation (shady). No. 1. Two Englemann's Iry on house; No. 2. Nine Spirea Van Houttei; No. 3. Eight Symphoricarpus, Indian Currant; No. 4. Two Rose of Sharon; No. 5. Twenty Japanese Barberry hedge along fence; No. 6. Ten Snowberry (corner clump); No. 7. Five Tamarix; No. 8. Five Rhodotypos; No. 9. Barberry Thunbergii; No. 10. Five Virginia Creeper; No. 11. Three Spirea A. W.; No. 12 One White Fringe between Nos. 8 and 10

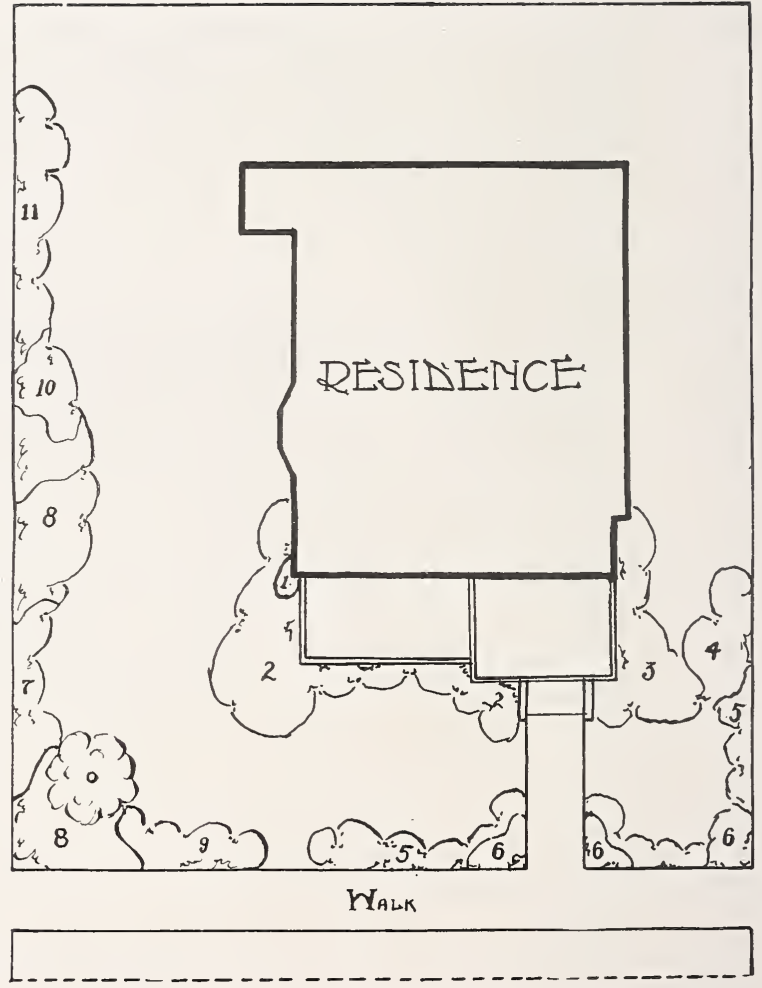




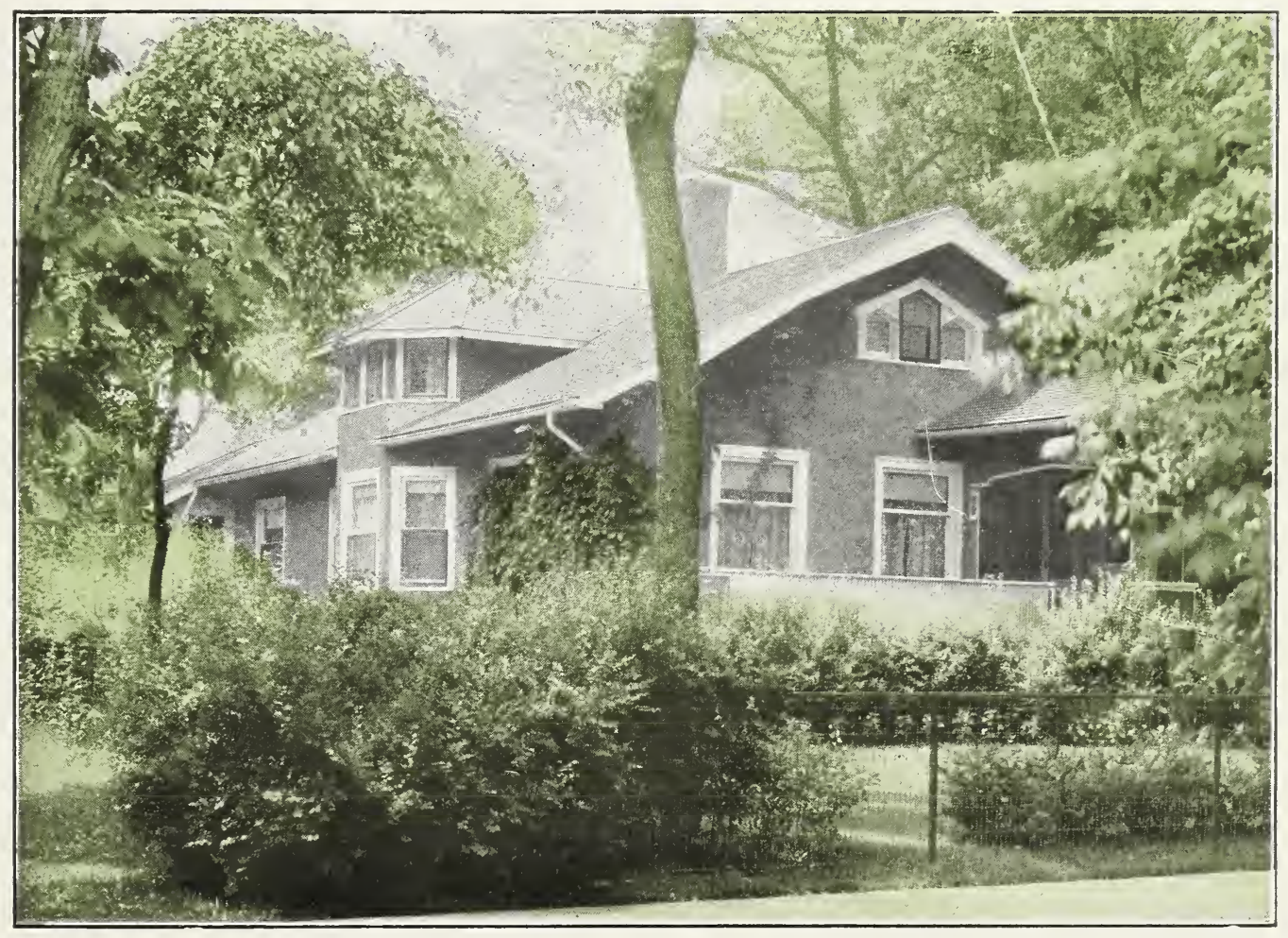




\section{A SUBURBAN HOME}

\section{Where Forest Trees Help}

The Landscape Gardener in drawing these plans treated the whole lot as a park, but unfortunately the back yard plantings do not show. Some people, however, prefer to have a vegetable garden in the back yard which in this case would not alter the pleasing appearance.

The clumps of shrubs in the corners of the yard consisting of two Thunbergii Barberries (2) (2), one Spirea Van Houttei (5) and four Spirea Argutas (7) can be used almost any. where. The Thunbergii Barberries at the front of the walk (2) (2) are largely planted.

The Tea's Weeping Mulberry at (17) is as good a specimen as can be placed in a small yard. They are interesting and do not interfere with the view of the house or from the window. If the walk is in the center of the yard as in this case you will want two.

The right hand foundation planting, seven Thunbergii Barberry (2); three Van Houttei Spireas (6); four Thunbergii Barberry (11); two Hydrangea P. G. (9) (9).

On the left hand side the foundation planting consists of group of four Thunbergii Barberry (2) and (2) and three Van Houttei Spireas (6).

The clump dividing the front and rear yard consisting of three Spirea Van Houttei (6), three Spirea Argutas (8) (8) (8), and four Barberries (2) (2) is available for many places. PLANTING LIST - No. 1. Two Rosa Rugosa; No. 2. One Thunbergii Barberry; No. 3. One Lombardy Poplar; No. 4. One American Elm; No. 5. One Spirea Van Houttei; No. 6. Three Spirea Van Houttei; No. 7. Four Spirea Arguta; No. 8. One Spirea Arguta; No. 9. One Hydrangea P. G.; No. 10. Three P. G. Hydrangea; No. 11. Four Barberry Thunbergii; No. 12. Four Siberian Dogwood; No. 13. Mock Orange; No. 14. Three Persian Lilac; No. 15. Common Snowball; No. 16. Silver Maple; No. 17. One Tea's Weeping Mulberry.

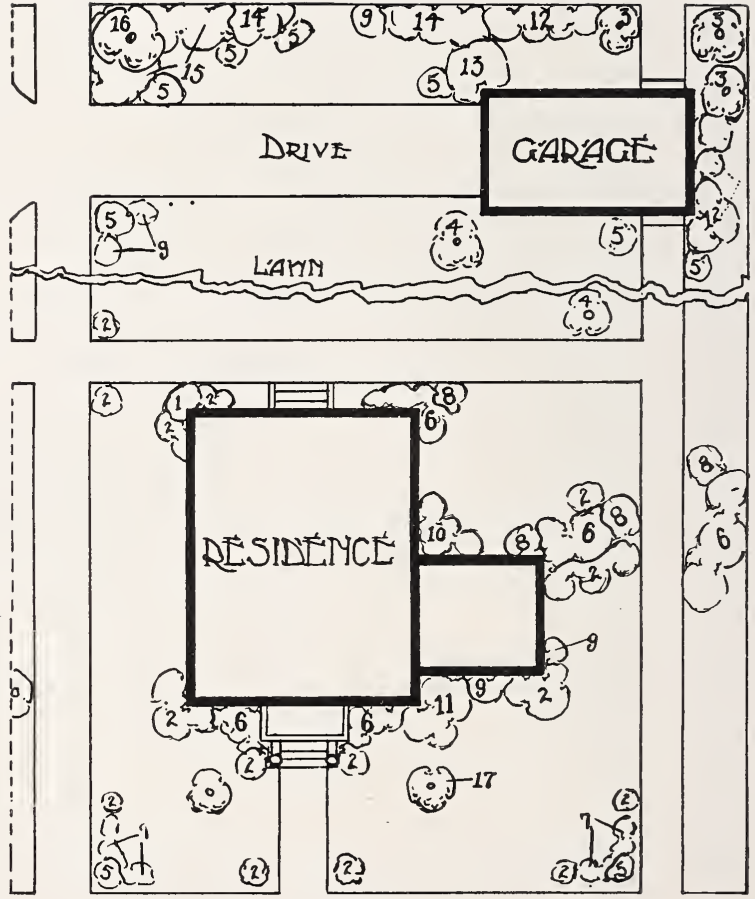

WALK

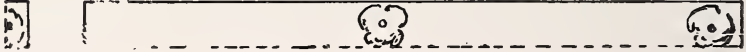




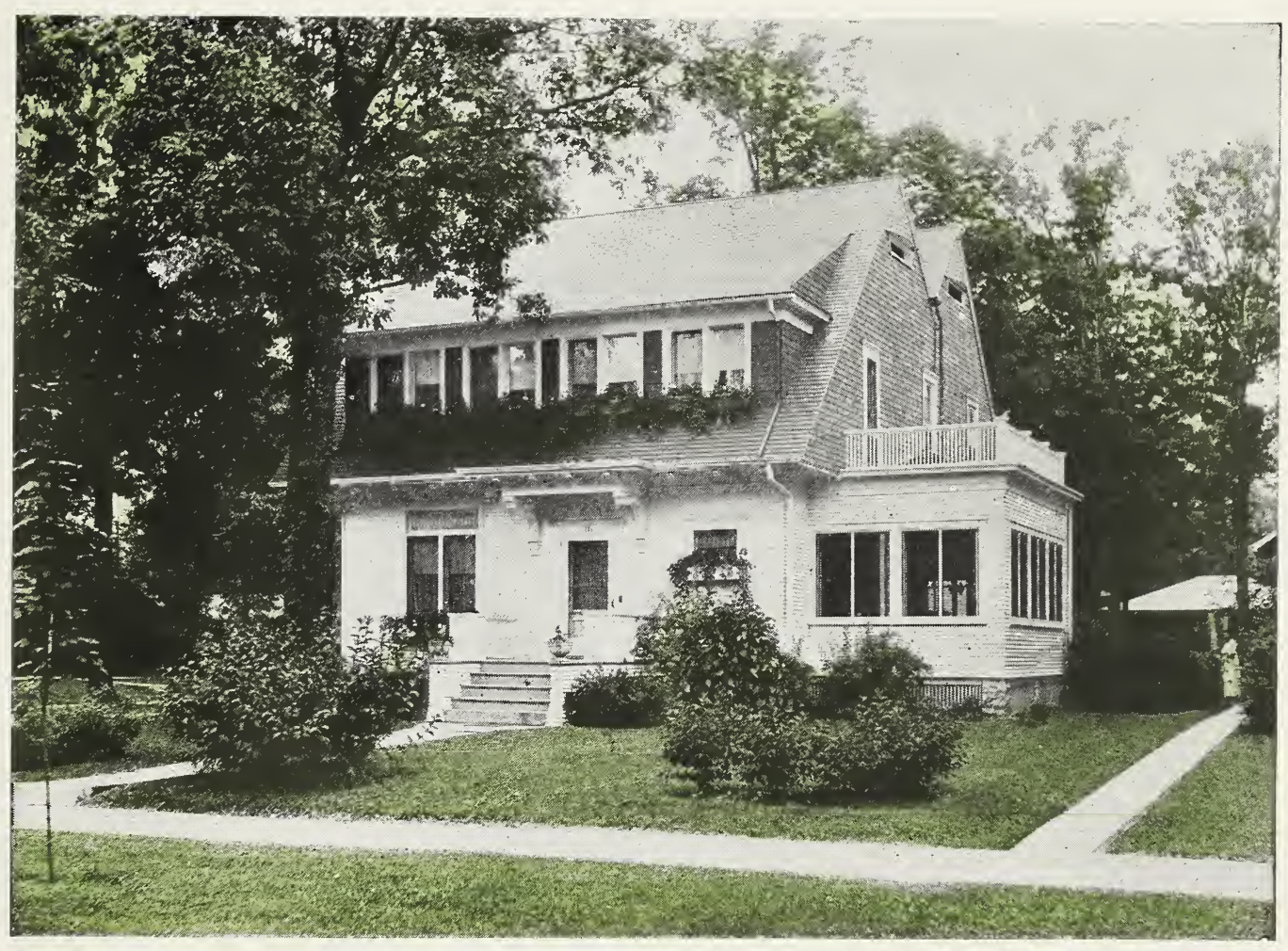




\section{A MASSIVE HOUSE}

\section{Turned Into a Home}

This would be a bare and barn like place if the help of the landscape gardener had not been invoked to make it inviting and lovely. No class of houses demand the planting of shrubbery as strongly as those of cement and stone.

This planting illustrates the superiority of the mass plan of planting and the beauty of an open lawn.

Vines add greatly to the appearance of stucco homes. On this home (1) Ampelopsis, Englemann's Ivy, has been used. The foundation planting is a very pleasing one, and consists of Philadelphus, Lemoine's Erect Syringa (5) with its sweetscented flowers in June; Indian Currant (4), and Barberry Thunbergii (3). Can be replaced by other shrubs of the same class if desired. The base of the shrubs in this foundation planting is covered $\mathrm{b} z$ a border of Hardy Phlox which has a wealth of beautiful bloom July-October. The planting opposite the steps has the same pleasing combination of plants with a Paper Birch with its beautiful white bark to contrast with the foliage of the shrubbery.

\section{PLANTING LIST}

No. 1. Englemann's Ivy.

No. 2. Hardy Phlox.

No. 3. Barberry Thunbergii.

No. 4. Indian Currant.

No. 5. Philadelphus, Lemoine's Erect.

No. 6. Paper or Canoe Birch.

No. 7. Pin Oak.

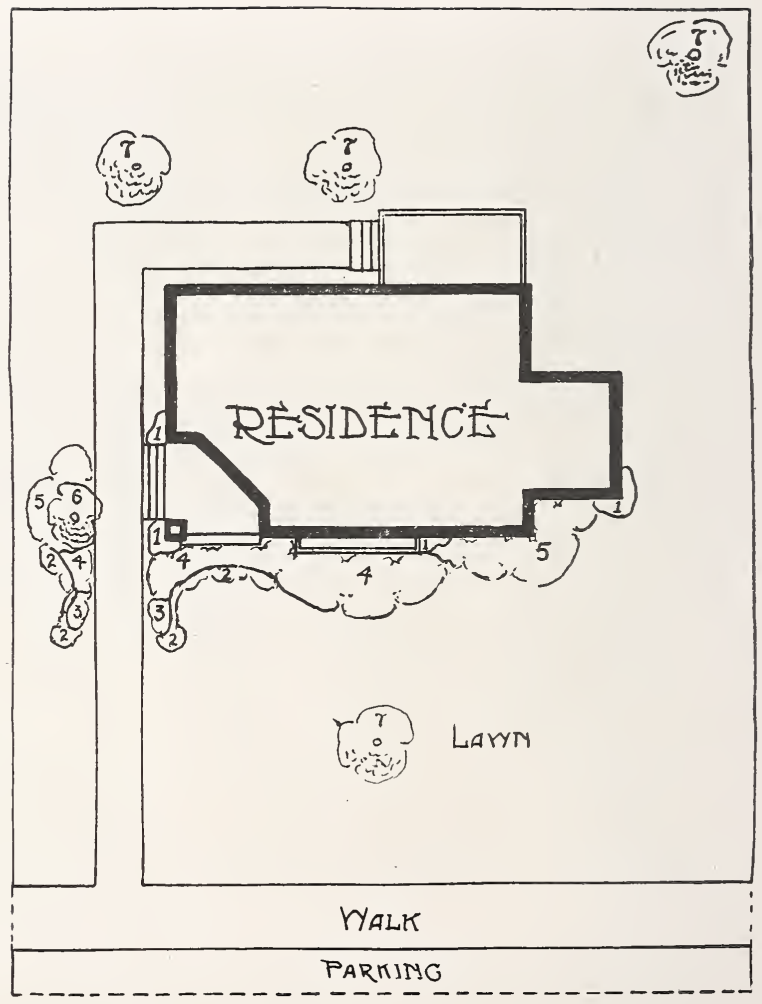




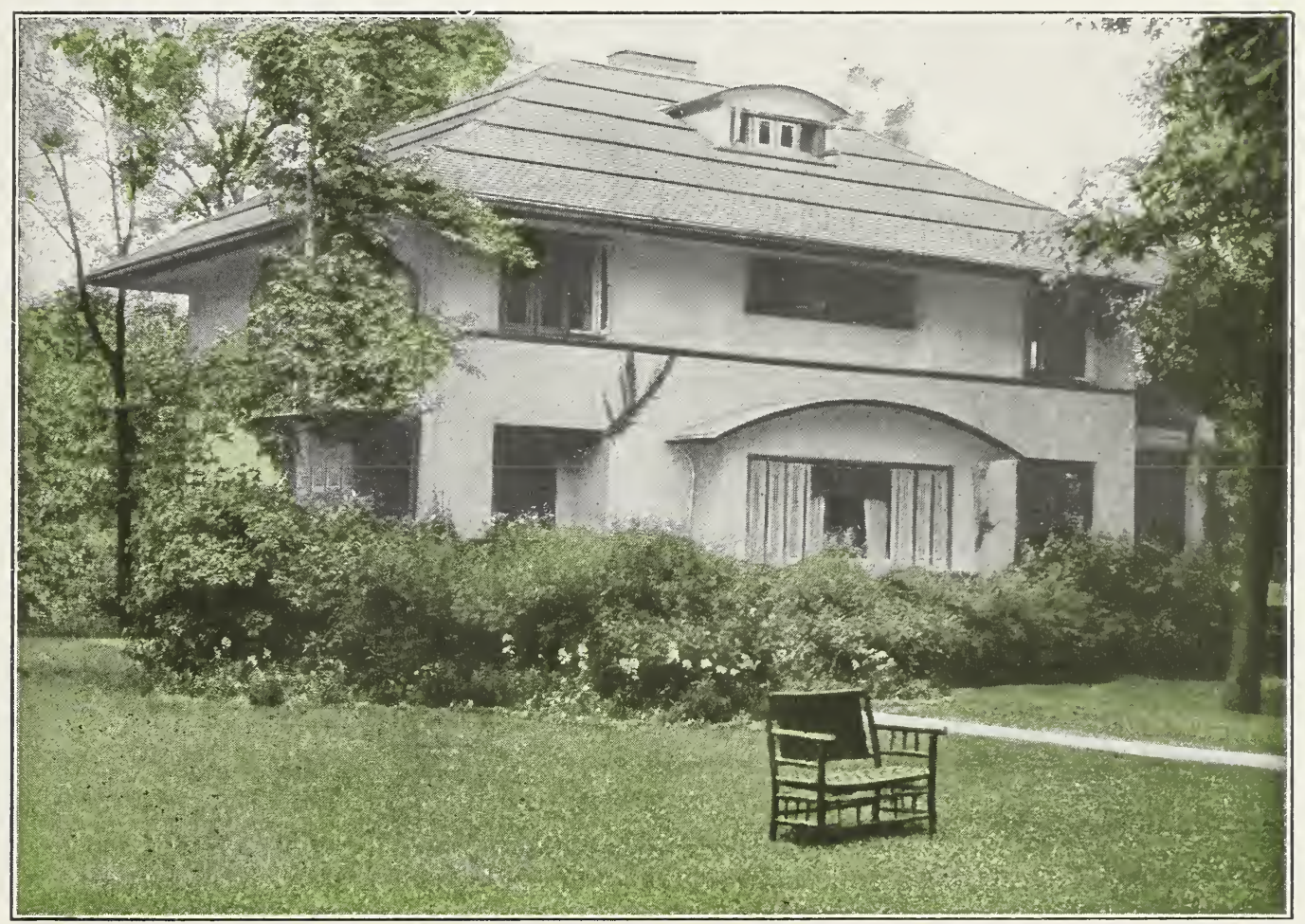




\section{A SUBSTANTIAL HOME}

\section{For Well-to-do People}

Unfortunately the picture shows but a small part of the planting that was done around this home, but the effect of the clump of three Spirea Van Houttei (5) at the right of the entrance, supported by six Thunbergii Barberries (3), may give you an idea for your own home. Such a group of nine plants would cost a moderate sum.

On the left hand side the two groups of Spirea Van Houttei (5) was flanked by a group of Rosa Rugosa Rubra (6) and the corner filled with a Philadelphus Coronarius (7). This clump of nineteen plants with a sketch for proper planting in the place you have for them is a desirable group.

Along the north side of this porch there is a splendid foundation planting-Philadelphus Lemoine's Erect Syringa (4), two Spirea Van Houttei groups (5) (5) and a border of Rosa Rugosa Rubra (6) requiring plants to cover a twenty foot space.

In front of the main building there is a very simple foundation planting of three Spirea Van Houttei (5) surrounded by 13 plants of the low growing Thunbergii Barberry.

PIANTING LIST-No. 1. Persian Lilac; No. 2. Spirea Thunbergii; No. 3. Barberry Thunbergii; No. 4 Philadelphus Lemoine's Erect, No. 5. Spirea Van Houttei, No. 6. Rosa Rugosa Rubra, No. 7. Philadelphus Coronarius, No. 8. Honeysuckle Japanese Bush; No. 9, Honeysuckle Fragrant Bush; No. 10 Lilac, Marie Lagraye; No. 11. Lilac, Pres. Grevy; No. 13. Viburnum-Sterelis; No. 14. Boston or Englemann's Ivy on fence; No. 15. Maples.

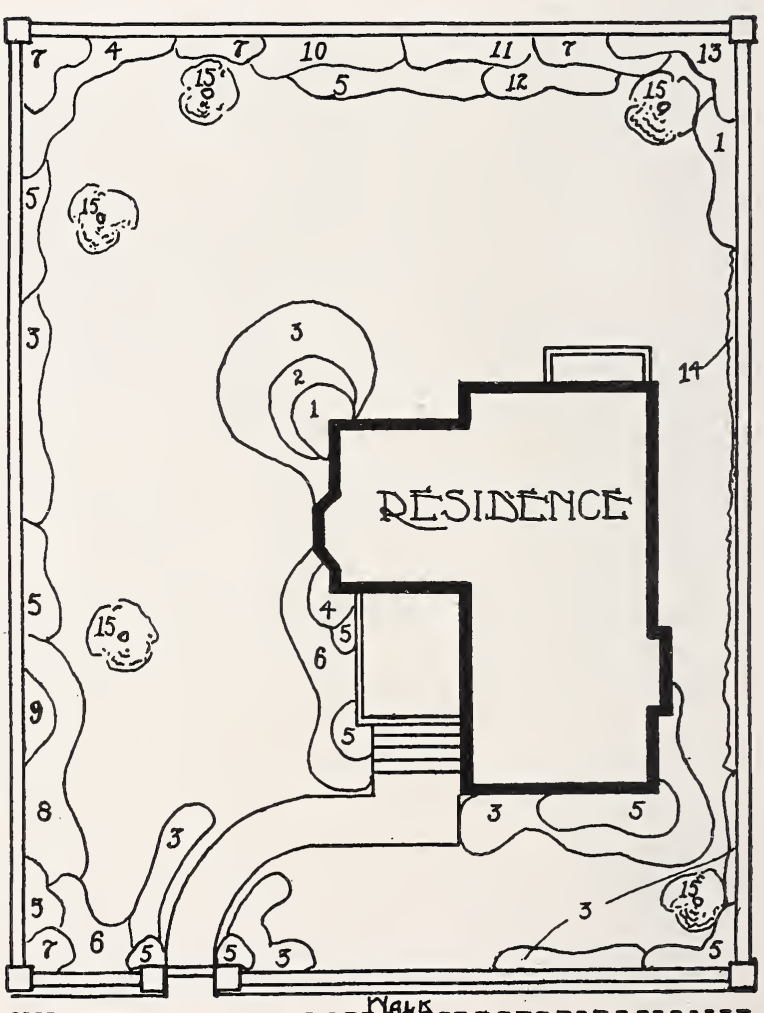




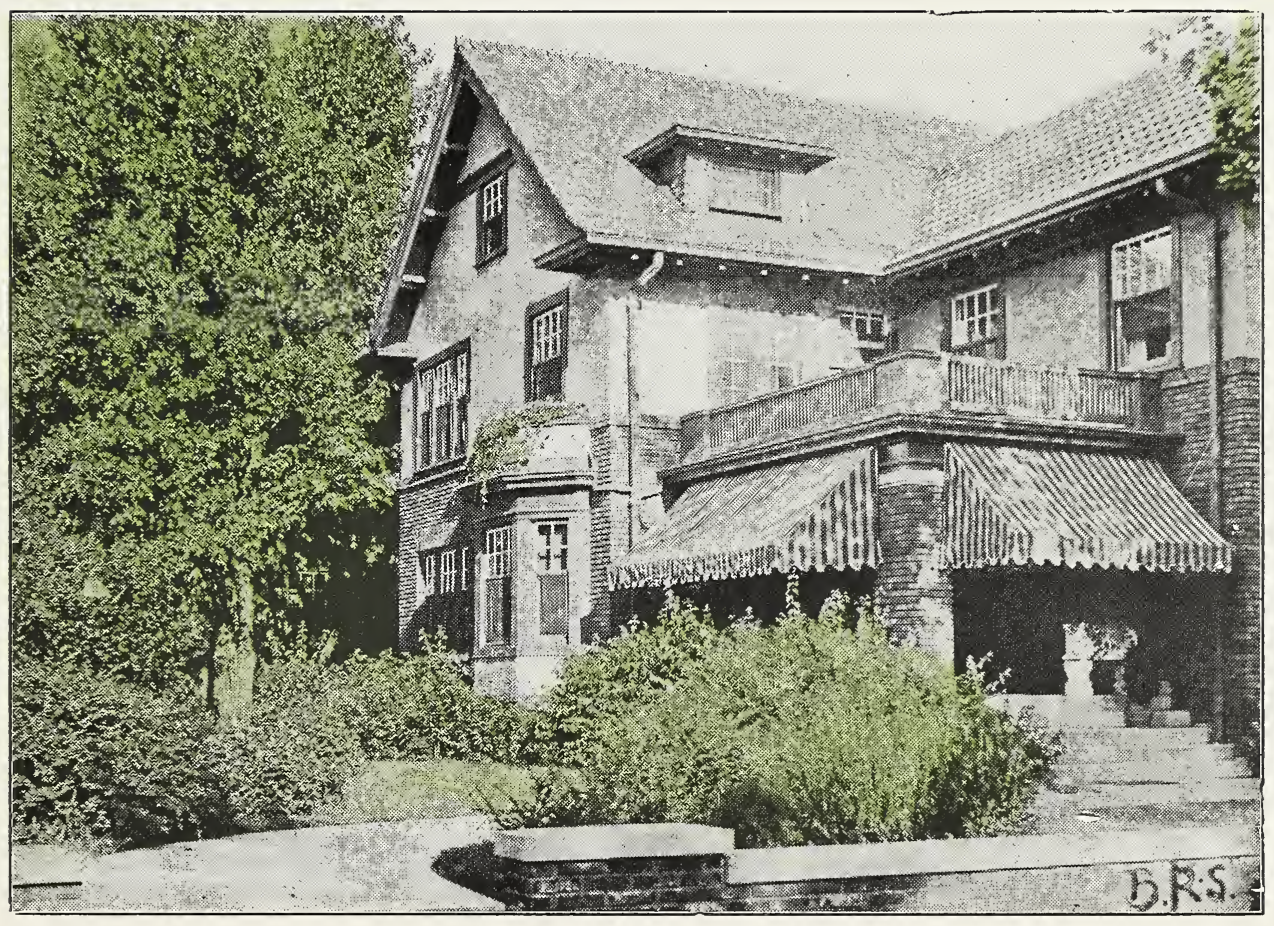




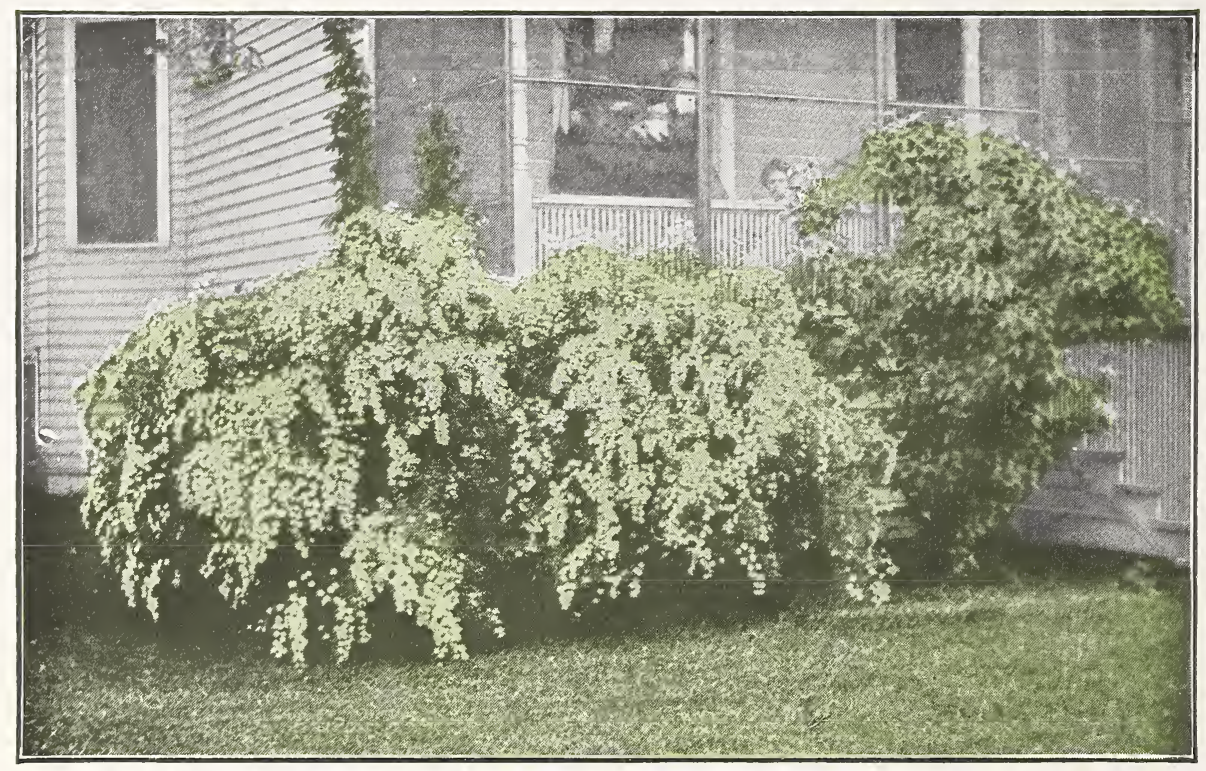

AN EXCLUSIVE SPIREA PLANTING. 


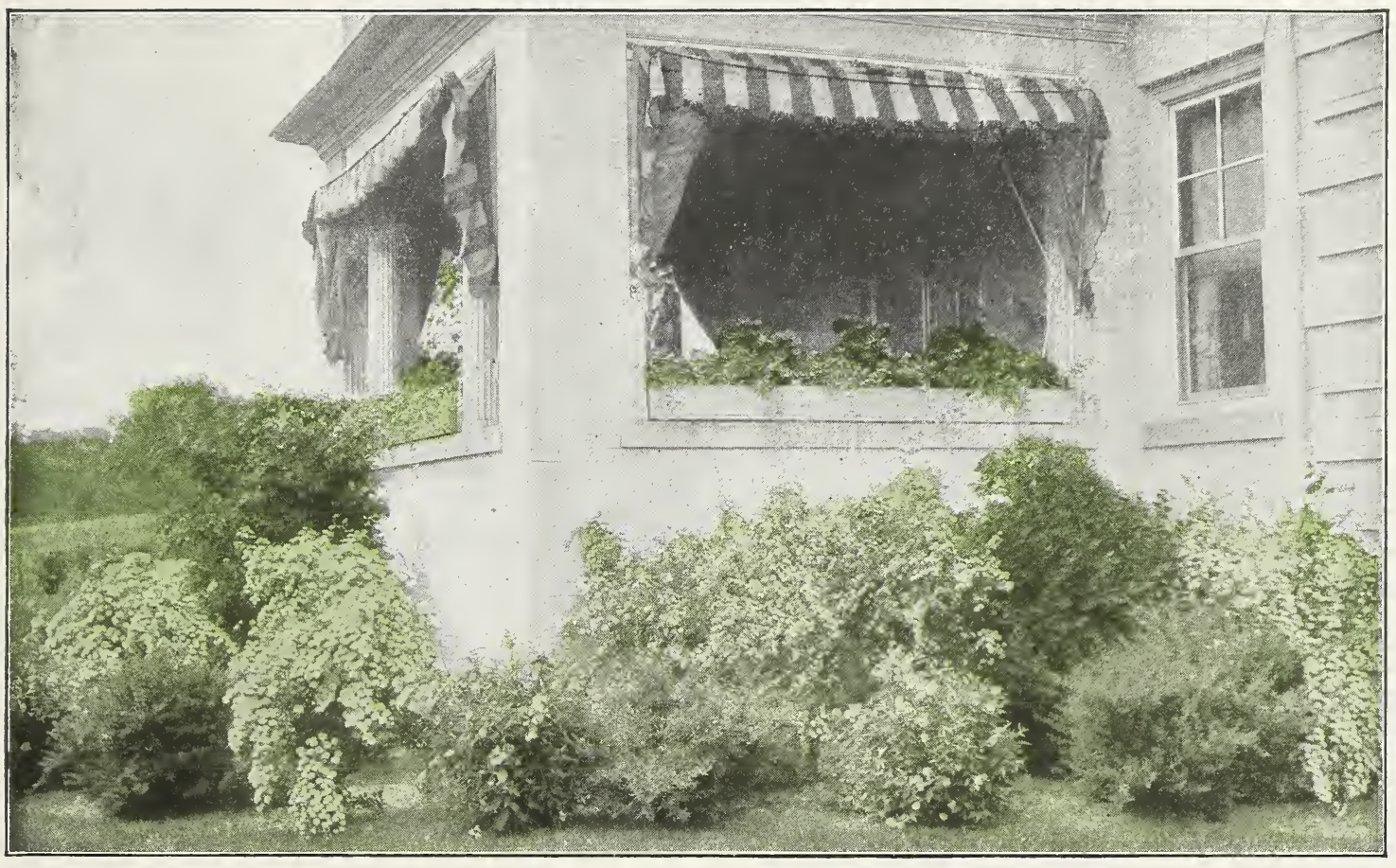

A FOUNDATION PLANTING WORTH IMITATING. 


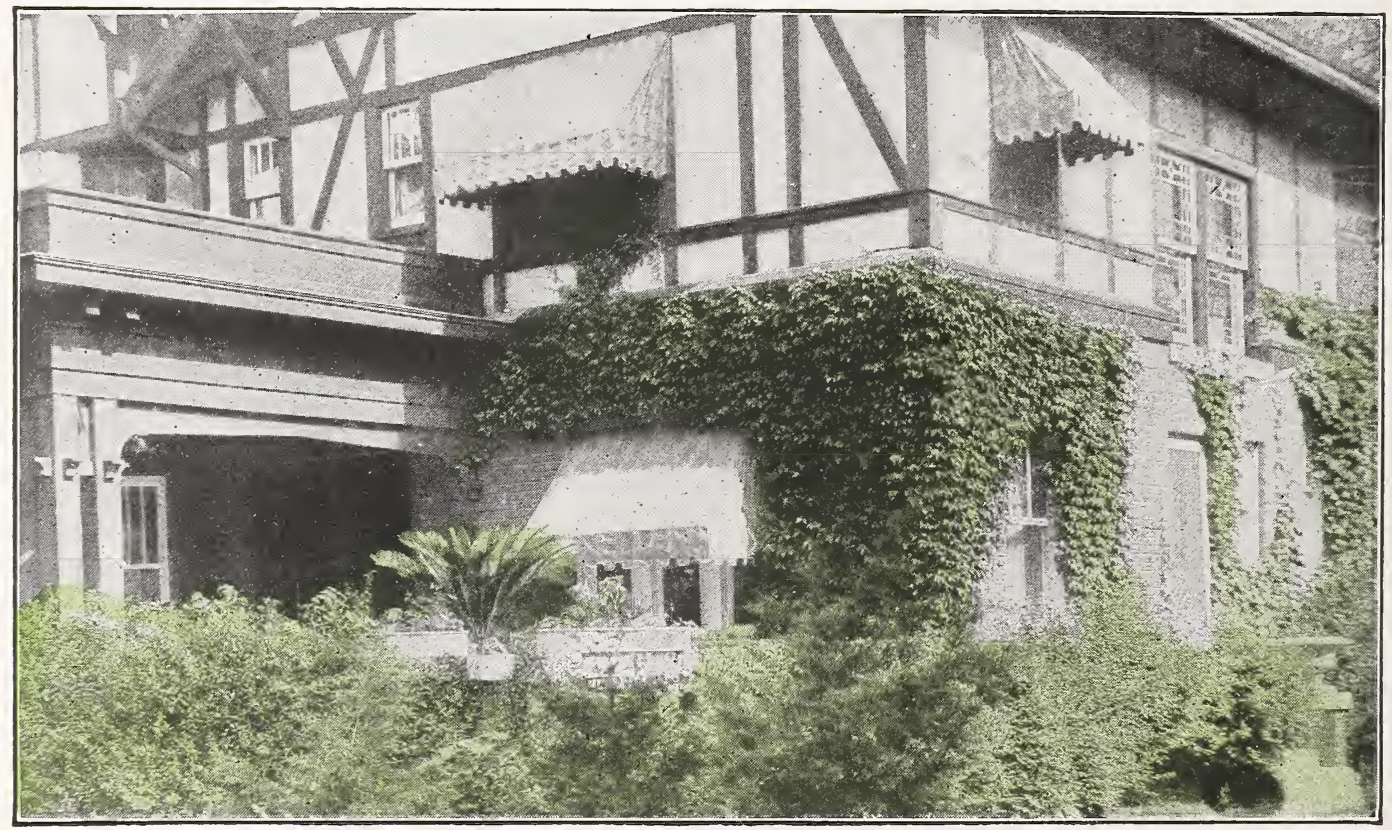

THE VALUE OF CLIMBING VINES. 


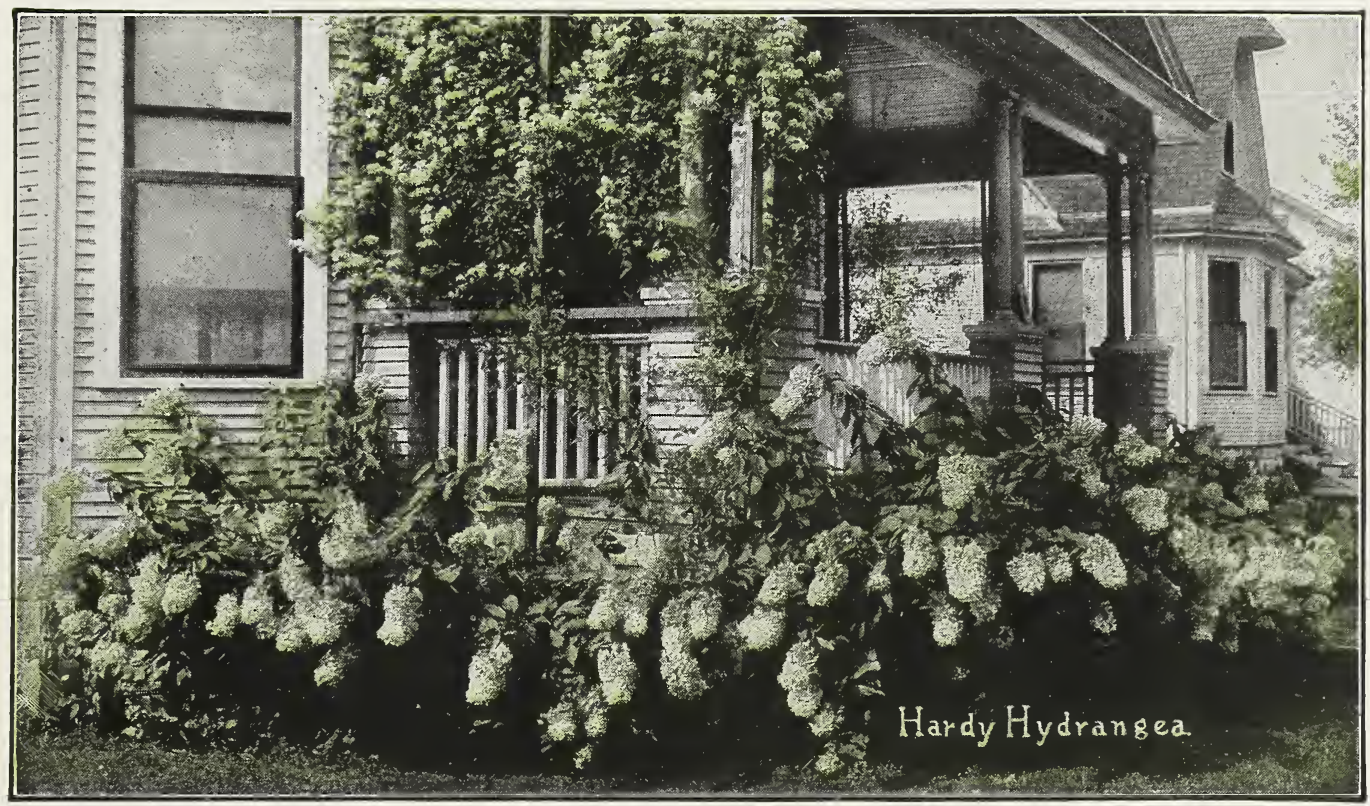

HYDRANGEAS MAKE MOST ATTRACTIVE RESULTS. 

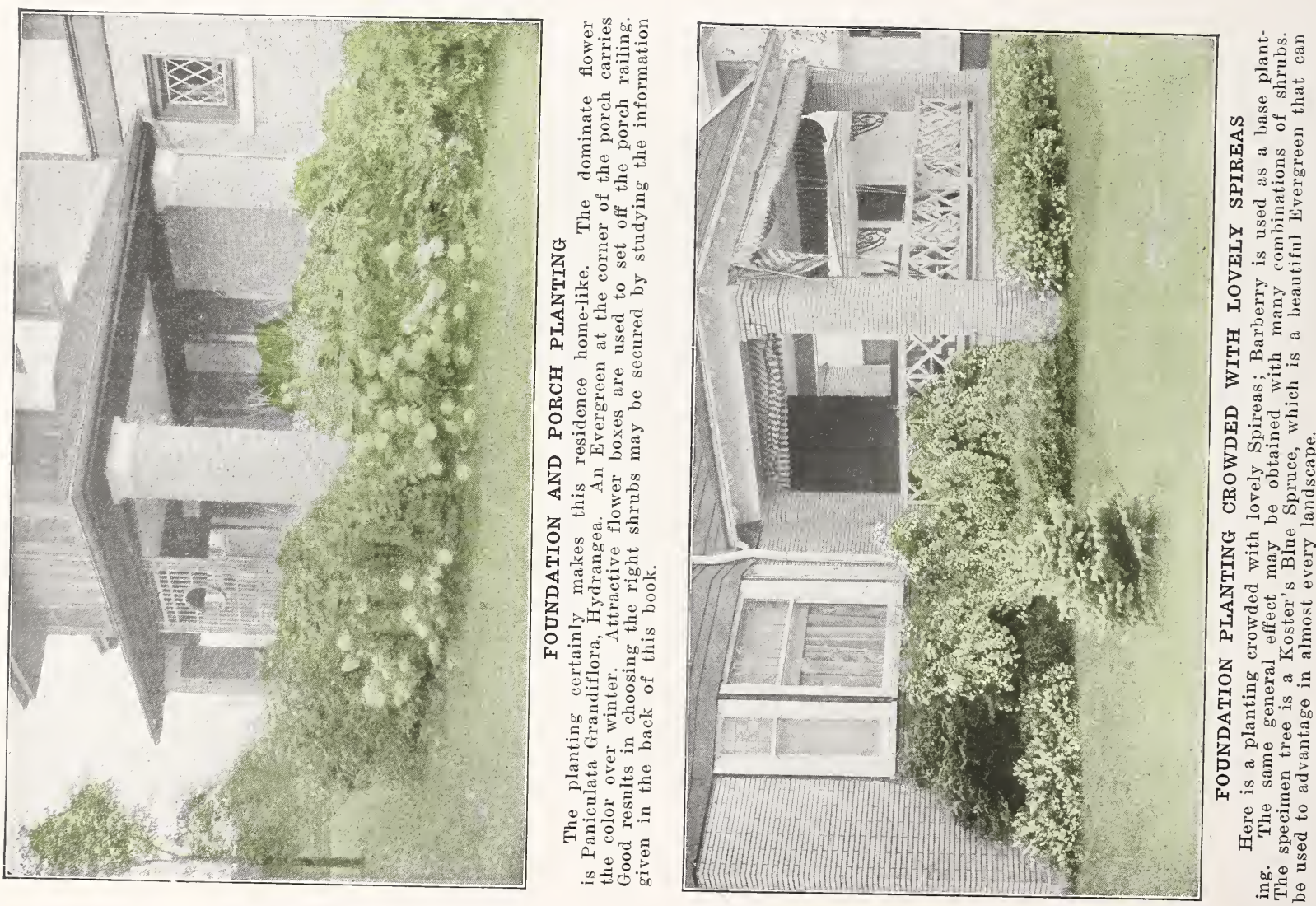

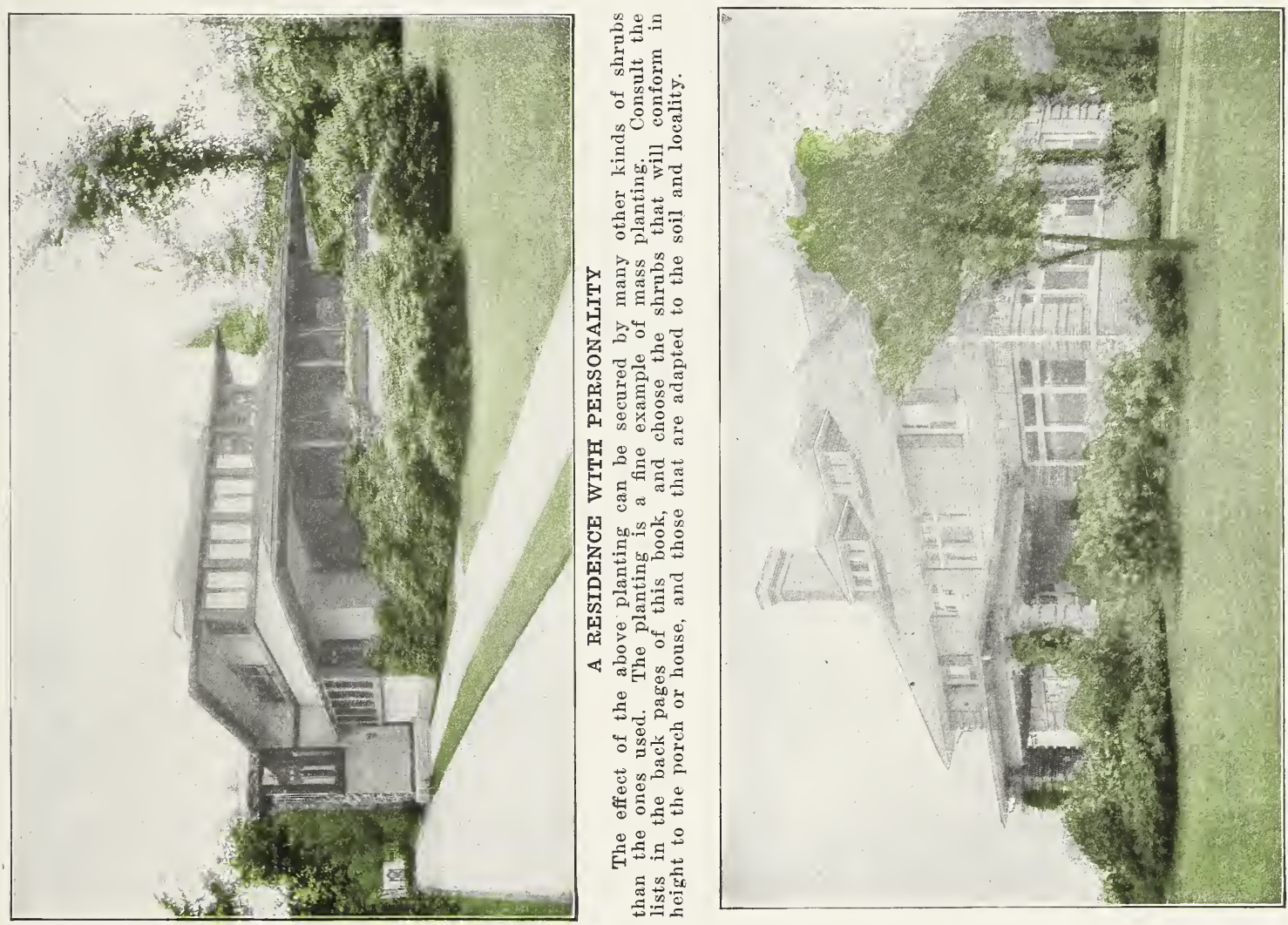

究

$\therefore$.

है

표 $:-\overrightarrow{1}^{0}$

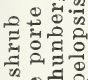

कै

सैमु

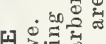

․․․

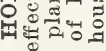

검웛윰

뜨

4 읭

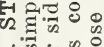

4 के 5 .

$\rightarrow-10$

है․ㅠ.

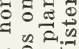

n)

๘灵

so 0.8

편

जี

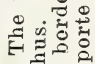

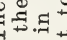

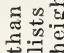

: 


\section{A COMPLETE CATALOGUE}

O $\mathrm{N}$ THE following pages of this booklet there is given a complete catalogue of the Trees, Shrubs, and Perennials usually planted in the different parts of the United States, listed under their normal size at maturity, and by a system of key letters their habits, uses, hardiness, and general qualities are given within a very small space.

There is no nursery catalogue known which lists so many varieties, because the catalogue is the sales agent of the nurseryman, and he cannot afford to catalogue anything that is not hardy, or in demand, in his territory, and it is no discredit to the nurseryman but a safeguard to his customers that should always be taken into consideration in making your planting list.

If you will study this catalogue in connection with the key letters, which are the most important part of it, as the other description is to be found in any catalogue, you have at your command a practical encyclopedia of the uses to which the Ornamental Trees and Shrubs of America can best be put. 


\section{DECIDUOUS TREES}

There are so many elements entering into the success of a plant or tree that in making a selection we recommend thst our customers pay particular attention to the key letters included in each of these descriptions, and make selections that will conform to the location and nature of the ground.

(a) - Trees for city street, road or wide avenue; (b)-Trees for driveways through lawn and parks; (c)-Quick growing trees for street; (d) - Lawn trees; (f) - Trees for sea shore planting; (g) - Trees for moist locations; (h)-For dry locations; (i) - For dry knolls of poor soil; $(\mathrm{j})$ - Massing; $(\mathrm{k})$ - Very hardy; (l)-Requires sheltered position; (m) - Requires shelter until established.

\section{Trees Especially Adapted to Lawn Specimens}

ALDER, European-c $\mathrm{g} f \mathrm{k} .30-60 \mathrm{ft}$. A remarkably fast growing tree, and has beautiful wavy, wedge-shaped foliage. ALDER, Imperial Cut-leaved-k d $\&$ g. 30-50-ft. Very graceful habit, having a mass of large deep cut green foliage. ALMOND, Davidiana-d $\mathrm{m}$ j. 8-10-ft. Good in shrubbery border; beautiful showy double rose-colored Aowers in May. AMELANCHIER (Juneberry) - k j. 10-15-ft. White flowers in May; the fruits are purple, ornamental, and edible. ARAIIA, Japonica (Angelica Tree)-d 1. 15-20-ft. Flowers in large white spikes in July; mammoth compound leaves. BEECH, American-a b d h k. 50-60-ft. A beautiful, stately spreading tree, and a very popular shade enduring species. BEECH, European-b d h j k. 40-50-ft. More compact than the American, smaller leaves, beautiful in spring coloring. BEECH, Purple-leaved (Copper)-d l. 40-50-ft. This tree is symmetrical in growth with its foliage purple to crimson. BIRCH, Cut-leaved Weeping-d 1. 40-ft. White bark; drooping branches; finely cut foliage; transplant in the spring. BIRCH, Pyramidal-d b k. 40-ft. Fastigiate in growth; bark white, habit like Lombardy Poplar; transplant in spring. CATALPA, Bungeil (Umbrella) $-\mathrm{b} d \mathrm{j} \mathrm{k}$. 15-ft. In formal gardens; white spotted flowers in July; round and compact. CEDRELA TREE, Chinese-c i k. 30-40-ft. White flowers in June; attractive feathery foliage; good in smoky cities. CHERRY, Double White Flowering-d j l. 10-15-ft. Completely covered with a mass of double white flowers in May. CHERRY, Double Pink Flowering-d j l. 10-15-ft. This variety has a profusion of double pink flowers in early May. CHERRY, Japanese Flowering-d j l. 10-15-ft. Flowers are very large, pink or blush color, and good for cut flowers. CHERRY, Japan Weeping-d j 1. 6-10-ft. Weeping form of the above with pink flowers; branches droop to the ground. CORNELIAN CHERRY -j 1. 10-12-ft. Showy yellow flowers in April before leaves put out; scarlet berries, shrub like. CRAB, Flowering (Betchel's)-d j k. 10-15-ft. For massing among the coarse shrubbery; pink rose-like flowers in May. CRAB, Flowering- $d j \mathrm{k}$. 10-15-ft. Rose colored flowers in May; the fruit is red, about the size of a pea; ornamental. CFPRESS, Deciduous (Bald) - b d f. 80-100-ft. A very pretty pyramidal tree; stately; has the sofest fleecy foliage. DOGWOOD, White Flowering-b d j k. 20-25-ft. White flowers in May; a very beautiful trec with scarlet berries. DOGWOOD, Red Flowering-b d $j \mathrm{k}$. Rare variety similar to the above but with handsome red flowers; very attractive. EIM, Camperdown-d k. 10-15-ft. Long pendulous branches; a strong and vigorous grower; very popular weeping tree. ELIM, Purple-leaved-a b d k. 40-50-ft. Bright colored purple leaves in early spring which changes to greenish.purple. EUONYMOUS (Spindle Tree)-d $j \mathrm{k}$. 30-40-ft. Yellow flowers in May; tree has very attractive foliage and fruits. FRINGE TREE, Purple or Smoke Tree-d j k m. 8-10-ft. Yellow green flowers in June changing to purple and plumose. FRINGE TREE, White-d j k. 10-ft. Fringe-like fragrant white flowers in May; has purple colored ornamental fruits. 


\section{Deciduous Trees Especially Adapted To Lawn Specimens-Continued.}

HORSE CHESTNUT, Ohio Buckeye-a d k. 30-40-ft. Yellow flowers in May, in large upright clusters; open in growth. HORSE CHESTNUT, Red Flowering-b d m. 20-30.ft. Showy clusters of large pink flowers in May; foliage deep green. HORSE CHESTNUT, White Flowering- $2 \mathrm{~b} d \mathrm{~m}$. 30-40-ft. Sterile form of the preceding but has white flowers in May. HORSE CHESTNUT, Double White Flowering- a d m. 30-40-ft. Sterile form of the preceding but has white flowers in May. JUDAS TREE (Red Bud) - b d j k. 15-ft. Rose pink flowers in April; a handsome spreading tree with good foliage. KENTUCKY COFFEE TREE-d k. 30-60-ft. Green-white flowers in June; very graceful tree and free from disease. LABURNUM, Golden Chain-b d m. 10.ft. Has long racemes of pea-shaped yellow flowers in June; dark green foliage. LINDEN, American (Basswood) - a b d k. 50.60-ft. Fragrant yellow flowers in July; leaves are large, smooth and showy. LINDEN, European (Lime Tree)-a b d k. 40-50-ft. Fragrant creamy white flowers in June; tree of pyramidal shape. LILAC, Japanese Tree-b c d j k. 20-30-ft. Thrives in shelter belts; has creamy white flowe $\tilde{I}_{0}$ in June and August. IINDEN, Weeping- a b c d k. 30-40-ft. Yellow flowers in July; the tree is somewhat pendulous with large leaves. LINDEN, White-leaved (Silver) - a b c d k. 40-50-ft. Pyrmidal compact head; under side of leaves of silvery-white. MAGNOLIA, Hall's-b d j m. 6-8-ft. Sweet scented white flowers in April; one of the earliest to bloom; dwarf habit. MAGNOLIA, Lenne's-a b d m. 10-15.ft. Has deep crimson flowers in May; somewhat later than Soulgeana; a hybrid. MAGNoliA, Soulgeana-a b d m. 10-15-ft. Sweet scented white flowers in May; the most popular variety of this treo. MAGNOIIA, Sweet or White Bay-b d $\mathrm{g} \mathrm{k} \mathrm{m}$. 20-30-ft. White flowers blooming in May and June; fragrant; attractive. MAPLE, Japan-d m. 10-15-ft. Very graceful and beautiful dwarf tree which has wonderful coloring during autumn. MAPLE, Schwedleri-a b d k. 30-40-ft. Handsome, with color changing foliage; crimson to green, red and brown. MAPLE, Wier's Cut-leaved-a b d k. 50-ft. May be severely pruned; graceful, pendulous, and a favorite with everyone. MOUNTAIN ASH, American-d k. 20-30-ft. Has white flowers in June followed by very attractive scarlet berries. MOUNTAIN ASH, European (Rowan Tree)-d k. 20-30-ft. White flowers in June and followed by bright red berries. MOUNTAIN ASH, Oak-leaved-d k. White flowers in June; brilliant red fruit clusters; pyramidal with upright branches. MULBERRY, Tea's Weeping-d k. 20-30-ft. Most graceful weeping tree grown; has very dense deep green foliage. OAK, Pin-a b d f g k. 40-60-ft. Tree of Pyramidal shape with beautiful crimson leaves in the fall after the first frost. PAGODA TREE, Japan (Sophora)-d m. 15-20-ft. Yellow-white flowers in July; the tree has a dense round head. PAULOWINA, Empress Tree-d l. 25-30-ft. Pink flowers in June; leaves sometimes are eighteen inches in width. PAWPAW-d k. 10-40-ft. Reddish brown flowers in May; landsome foliage; edible fruit; novel; very effective treo. PEACH, Flowering (Double Red and Double White)-d $\mathrm{m} \mathrm{j}$. Good when used with coarse shrubs; beautiful flowers in May. PLUM, Pissardi or Purple-leaved- $d \mathrm{k} j$. 8-10-ft. Pink flowers in May; effective among tall shrubs for color contrast. SALISBURIA, Maiden Hair or Ginkgo-d m. 50-ft. Pyramidal tree with fan-shaped leaves; picturesque and attractive. SASSAFRAS-d b k. 20-25-ft. Fragrant yellow flowers, May; ornamental bark; foliage brilliant orange and red in fall. SILVERBELL (Halesia) - d $\mathrm{f} j \mathrm{~m}$. 10-12.ft. White flowers like snowdrops in May; the fruit has four papery wings. SOURWOOD or Sorrel Tree-d l. 10-ft. Lily-of-the-Valley-like flowers; white in August; tree has peach like leaves. SYCAMORE, American (Buttonwood) - a b d f g. 50-60-ft. A beautiful majestic tree with its bright green foliage. THORN, Flowering Cockspur-d k j. 12.ft. Used for hedges, screens; white flowers in May followed by scarlet berries. 


\section{Deciduous Trees Especially Adapted To Lawn Specimens-Continued.}

TUIIP TREE-a b d m. 40-60-ft. Tulip-like green-yellow flowers in June; a pyramidal tree with fiddle-shaped leaves. VARNISH TREE- $d \mathrm{~m}$. 25-30.ft. Tree has large yellow panicles of flowers in July; pretty blue-green colored leaves. VIRGINIA IUTEA, Yellow-wood-b d k. 30-ft. Fragrant white pea-shaped flowers in June. A very handsome tree. WALNUT, Black-k. 50-70-ft. Majestic tree attaining great size; edible nuts borne in great quantity; wood valuable. WILLOW, American Weeping-d g k. 8-10-ft. Slender drooping branches, sweeping outward in graceful fountain shape. WILLOW, Babylonica-d $\mathrm{f} \mathrm{g} \mathrm{k} \mathrm{m.} \mathrm{30-40-ft.} \mathrm{Branches} \mathrm{olive-green} \mathrm{color,} \mathrm{slender} \mathrm{and} \mathrm{drooping;} \mathrm{attractive} \mathrm{near} \mathrm{water.}$ WILLOW, Kilmarnock-d $\mathrm{g}$ k. 8-10/ft. Branches spreading and drooping, forming a picturesque umbrella-like head. WILLOW, Wisconsin Weeping- $\mathrm{d} f \mathrm{~g}$. 30-40-ft. Very attractive near water; good to contrast with upright trees.

\section{Trees Especially Adapted to City Streets, Roads and Avenues}

ALANTHUS (Tree of Heaven) - a c i k. 40.ft. Green-white flowers in June, unexcelled for smoky city; tropical foliage. ASH, American (White) - a b d c k. 50-60-ft. Smooth gray bark; glossy leaves not subjected to attacks by insects. ASH, Green-d k g. 40-50-ft. Tree with shapely round topped head with dark green leaves; useful as a shade tree. BIRCH, Canoe or Paper-a b c d k. 50-ft. Open in growth; bark silvery white, smooth; effective among evergreens. ELIM, American-a b d j k. 60-80-ft. Graceful drooping branched tree; a great favorite with the American people. ELIM, English-a b d k. 60-80-ft. Branches sureading, forming a round open head; foliage is darker than American. ELIM, Scotch-a b d k. 50-60-ft. Resembles the English; leaves broadly ovate; very rough; remains fresh until late. GUM, Sweet-a b d k m. 40-ft. Green flowers in April; maple like leaves; brilliant in the fall; has corky-ridged bark. HACKBERRY, Nettle Treo-a d k. 40-ft. Branches are slender, drooping; brownish-black berries throughout the winter. LARCH, American or Tamarack-a b d f g k. 50-ft. Very ornamental, pyramidal growth; good for use with evergreens. MAGNOLIA, Cucumber Tree- $k \mathrm{~m}$ b. 50-80-ft. Yellow-green flowers in May; leaves are large; fruit is rosy red color. MAGNOLIA, Umbrella Tree- $\mathrm{d} \mathrm{f} \mathrm{k.} \mathrm{30-40-ft.} \mathrm{White} \mathrm{flowers} \mathrm{in} \mathrm{May} \mathrm{and} \mathrm{June;} \mathrm{leaves} \mathrm{are} \mathrm{large,} \mathrm{fruit} \mathrm{is} \mathrm{oblong} \mathrm{and} \mathrm{pink.}$ MAPLE, Norway-a b d f k. 50-60-ft. Beautiful; handsome tree with spreading branches, forming a dense round head. MAPLE, Silver-b c i k. 50-ft. Spreading growth; leaves deeply cut and light green, turning to gold in the autumn. MAPLE, Sugar or Rock-a b d k. 30-40-ft. Straight and spreading; dark green leaves turning to scarlet in the autumn. MAPLE, Sycamore-a b d k. 30-40-ft. Horizontal and spreading, with round head; bark is smooth; leaves are large. OAK, Burr (Mossy Cup) - a b d k. 60-100 ft. Grows with massive open growth; large leaves; deeply corrugated bark. OAK, Red-a b d f h k. 60-80-ft. Unusually large of leaf and quick in growth; foliage purplish crimson in autumn. OAK, Scarlet-a b d h k. 60-80-ft. Valuable for its brilliant fall coloring; of a rather narrow and open growth; hardy. OAK, White-a b d k. 100-ft. Tree has spreading branches with a broad open head; foliage red-purple in the autumn. POPLAR, Carolina-a c f i k. 40-50-ft. Pyramidal in form with large glossy leaves; succeeds everywhere it is planted. SYCAMORE, European (Oriental Plane) - a b d f g. 50-60-ft. Wide spreading tree; heart-shaped leaves; attractive bark. 


\section{Trees Especially Adapted for Hedges, Screens, Wind Brakes, Mass Planting}

BIRCH, European White-d a b k. 40-50-ft. Beautiful; white bark, spray-like lranches; effective with evergreens. BIRCH, Purple-leaved-3 l. 30-ft. Deep purple foliage in the spring fading to deep green in mid-summer; open growth. CATAIPA, Speciosa-a c d j k. 40-ft. Fragrant white flowers in July; open irregular growt's; large heart-shaped leaves. GOM, Sour (Tupelo) - a d f g k. 40-50-ft. Picturesque tree with peculiar twiggy branches; very beautiful fall coloring. HOP HORNBEAM, Ironwood-d h k. 15-ft. Birch-like in appearance, and conspicuous bladder-shaped fruit in clusters. HOP TREE or Wafer Ash-j k. 8-10-ft. Hop-like fruits in late summer; the leaves have a hop-like odor when bruised. HOP TREE, Golden-j k. 8.10-ft. A variety of the above with golden foliage which holds its color throughout the season. KADSURA TREE-b d m. 25. ft. Remarkably beautiful; heart-shaped leaves; purple in the spring; an ornamental tree. MAPLE, Ash-leaved (Box Elder) -c d i k. 40-50-ft. For shelter belts; has spreading growth habit; leaves light green. LOCDST, Black-k. 20-30-ft. Tree has very fragrant yellow-white flowers in June; good tree in sehlter belts. IOCUST, Honey-a b d f k. 40-ft. Makes impenetrable hedge if pruned severely; tree has pink flowers in May; hardy. POPIAB, Bolleana-c f i k. 60-80-ft. A tall columnar tree and is useful for formal gardens and architectural effects. POPLAR, Lombardy-c $\mathrm{f} \mathrm{i} \mathrm{k.} \mathrm{60-80-ft.} \mathrm{Colnmnar} \mathrm{in} \mathrm{growth;} \mathrm{remarkable} \mathrm{for} \mathrm{its} \mathrm{erect} \mathrm{growth;} \mathrm{spire-like} \mathrm{in} \mathrm{form.}$ THORN, Double White-d k. 15-ft. Large, showy white flowers blooming in May; tree has open habit of growth. THORN, English Haw-d k j-10-ft. Pure white flowers blooming in May; makes excellent hedge; the berries are red. THORN, Paul's Double Scarlet-d k. 15-ft. Numerous carmine flowers in May; tree has rather open habit of growth.

\section{EVERGREENS Including Trees and Shrubs}

(a) - For landscape groups, screens and wind brakes; (b)-For specimens; (c)-For formal effects; (d)-For informal plantings; (e)-Comparatively rapid in growth; (f)-Slow in growth; (g)-Very hardy; (h)-Requires sheltered position; (i) -Requires shelter until well established; $(j)$ - Thrives in any good soil; $(k)$ - Prefers moist soil; (1)-Best in light soil; (m)-Hedges, mass planting.

ABIES, Balsam Fir-b $\theta \mathrm{g}$ k. 50-60-ft. Foliage is sweet-scented and dark green; a broad, regular pyramidal tree. ABIES, Con Color, or White Fir-b e g j. 40-50.ft. A beautiful Evergreen with large silver-blue foliage; ornamental. ABIES, Nordman's Fir-b e h l. 30-40-ft. Symmetrical in growth with dark coarse foliage which is silvery underneath. ARBOR VITAE, American (Thuya) - a b c e $j \mathrm{~m}$. 15.20-ft. Branches are short and horizontal, narrow pyramidal tree. ARBOR VITAE, George Peabody's Golden (Thuya)-a b c e g j m. 10-15-ft. Pyramidal form with bright golden foliage. ARBOR VITAE, Globe-b c $f \mathrm{~g}$ j. 2-3-ft. Dwarf globose form with attractive bright green foliage; upright branches. AR3OR VITAE, Oriental-b c f h j. 10-15. ft. Tall, columnar in form; color dark green with lighter tips of new growth. ARBOR VITAE, Golden Oriental-b c f h j. 10-15-ft. A form of the above but with golden-green colored foliage. ARBOR VITAE, Pyramidal (Thuya) -a b c e $\mathrm{g} \mathrm{m}$. 10.15.ft. Very hardy variety; narrow, columnar shape; attractive. 
Evergreens, Including Trees and Shrubs-Continued.

ARBOR VITAE, Siberian (Thuya) - a b c e $\mathrm{g} j \mathrm{~m}$. 10-15.ft. In growth like American; foliage heavy and blue.green. ARBOR VITAE, Tom Thumb-b c f $\mathrm{g} \mathrm{j} \mathrm{m.} \mathrm{2-3-ft.} \mathrm{Very} \mathrm{dwarf} \mathrm{and} \mathrm{compact;} \mathrm{a} \mathrm{very} \mathrm{popular} \mathrm{tree} \mathrm{for} \mathrm{decorating} \mathrm{purposes.}$ ARBOR VITAE, Vervaeneana-b $\mathrm{c} f \mathrm{~g} \mathrm{j} \mathrm{m}$. 10-15. ft. Erect habit and form like American; golden variegated foliage. CHAMAECYPARIS, Nootka Sound Cypress-b c $f \mathrm{~g} \mathrm{j}$. 20-30-ft. Tree has glaucous green leaves and spreading branches. HEMLOCK, American-a b e g j k. 50.60.ft. Yew-like foliage; will stand much pruning; endures the shade well. JUNIPERUS, Irish Juniper-b $\mathrm{c}$ e h j. 8-10-ft. Columnar in growth with upright branches and leaves of a light green. JUNIPERUS, Savin Juniper-a b d e g j. 3-4-ft. Attractive; good for hillside; branches are spreading or procumbent. JUNIPERUS, Red Cedar-a b e g j. 20-30-ft. Generally conical in shape; branches are upright; foliage is dark green. JUNIPERUS, Silvery or Blue Cedar-a b e g j. $15-20 \mathrm{ft}$. A very vigorous growing form of the preceding variety. PINE, Austrian-a b e g j. 40-50-ft. Spreading; long, dark green, rigid foliage; very good for use near sea shore. PINE, Mugho or Dwarf Mountain-a b d f.g j. 3.10-ft. Good on rocky slopes; very handsome spreading evergreen. PINE, White - a b e g j. 50-75-ft. Very picturesque when old and adapted for large grounds; the foliage is blue-green. PINE, Scotch-a b e g j. 40-50-ft. Thrive in poor soils; spreading habit in growth; the foliage is blue-green color. RETINOSPORA, Plumed Cypress-a b c g i j. 10-15-ft. Foliage dense, glstaras and delicate; exceedingly handsome. SPRUCE, Colorado Blue a b f g j. 50-60-ft. Branches are horizontal; the foliage is a blue-green to a silvery-white. SPRUCE, Kosters Blue-a b f $\mathrm{g} j$. 50-60-1t. The bluest and finest of blue spruces; form very similar to the Colorado. SPROCE, Norway-a b e $\mathrm{g} j \mathrm{~m}$. 50-60-ft. Picturesque and beautiful; the most widely planted variety of the Spruce. SPRUCE, White or Hemlock-b e g j. 50-75-ft. Pyramidal and dense in growth; foliage silvery.green; very ornamental. TAXUS, English Yew-b c d h k m. 10-15-ft. Not hardy north of New York City; resembles the native Hemlock tree. YEW, Japanese-a b d g J. 3-4-ft. Spreading and irregular in growth; foliage coarse and glossy green; hardiest of Yews. YEW, American-a b d h k. 3-4-ft. Good on banks and under trees; ornamental crimson fruit in winter; low and spreading.

\section{Broad Leaved Evergreens}

BUXUS, Box Tree-b c f h k. 5-10-ft. A small tree of great beauty; can be trained to any desired form by shearing. BUXUS, Box Bush or Dwarf-c f h k m. 1.2-ft. Undoubtedly the best plant in cultivation for edging and border uses. DAPHNE, Garland Flower-f 1 i. 8-inch. Pink flowers in March; good in rockery; fragrant flowers in close clusters. EUNYMOUS RADICANS-See "Evergreen Ivy" under vines for a complete detailed description of this evergreen vine. KALIMIA, Mountain Laurel or Calico Bush-a b f g k m. 5-10-ft. Rose to white flowers in May-June; good along streams. MAHONIA, Aquifolia, Ashberry or Oregon Grape- b $\mathrm{f} \mathrm{i} \mathrm{j} \mathrm{m.} \mathrm{4-5-ft.} \mathrm{Yellow} \mathrm{flowers.;} \mathrm{May;} \mathrm{holly-like} \mathrm{leaves} \mathrm{turning} \mathrm{in} \mathrm{fall.}$ PIERIS, Floribunda, Lily-of-the-Valley Shrub (Andromeda)-b $f \mathrm{i} \mathrm{j} \mathrm{m.} \mathrm{2-3-ft.} \mathrm{White,} \mathrm{delicate} \mathrm{flowers} \mathrm{in} \mathrm{May} \mathrm{and} \mathrm{June.}$ RHODODENDRON, Catawbiense-a b i k m. 6-8-ft. Lilac-purple; beautiful shrub with peony-like flowers in June. RHODODENDRON, Maximum, Giant Bay or Great Laurel-a b g i k m. 8-10-ft. Rose, June-July; spreading in growth. 


\section{HARDY SHRUBS}

(a)-For the Rockery; (b) - For bog gardens or wet places; (c)-For hedges or screens; (d)—For massing: (e)-Fur shrubbery border; ( $f$ )-For ground covers; $(g)$-For banks or waterside; (h)-For formal gardens; (i) - For specimens; $(\mathrm{j})$-For sea shore planting; $(\mathrm{k})$-Very hardy; (1)-Requires sheltered position; (m) -Requires shelter until well established; ( $n$ - - Prefers sunny situations; (o) - Prefers shady situations; $(p)$ - Succeeds well in dry soil.

\section{Hardy Shrubs Under Five Feet}

BARBERRY, Thunbergil, Japanese-c d k. Yellow flowers in June; superb foliage coloring in the fall; colored fruits. CYTISUS, Scotch Broom-e $\mathrm{j}$. Pear-shaped yellow flowers in May; fine dark green foliage; a very handsome shrub. DAPHNE, Cueorum, Garland Flower-a e. See "Daphne" listed under broad leaved evergreens for detailed description. DESMODIUM, P., Sweet Pea Shrub-e m. Pendulous sprays of pea-shaped magenta flowers, September; semi-herbaceous. DEUTZIA, Gracilis, Slender-d e i k. Numerous white flowers blooming in May and June; slender arched branches. DEUTZIA, Lemoine's-d e i k. Panicles of extra large white flowers in June; a very attractive and beautiful shrub. HYPERICUIN, Mosenianum (St. John's Wort) - a d e $\mathrm{k} \mathrm{n}$ o. Double yellow flowers in July-September; excellent foliage. RHUS, Aromatica, Fragrant Sumac-a d e $f \mathrm{~g} \mathrm{k} \mathrm{p}$. Yellow flowers in May; leaves trifoliate, aromatic; fruit bright red. RHUS, Capallina, Shining Sumac-d e $f \mathrm{~g} \mathrm{k}$ p. Yellow green flowers, July-Aug.; glossy deep green foliage, turning crimson. SPIREA, Arguta (Snow Garland)-c d e i k. Flowers in clusters along drooping slender branches, May; very ornamental. SPIREA, Bumalda-d e i k. 2-3-ft. Light pink flowers in July and August; showy flat clusters; good, dense foliage. SPIREA, Anthony Waterer-d e i k. 2-3-ft. Very similar to the above variety except with showy crimson flowers. SPIREA, Callosa alba (Japonica) - d e i k. 2-3.ft. White flowers June to September; dull green leaves; upright growth. SPIREA, Fortunei-c d e i k. Deep pink flowers June to September; upright branches; deep green foliage; attractive. SPIREA, Thunbergii-c d e i k. White flowers in April and May; retains delicate foliage until late in the autumn. STEPHANANDRA, Flexuosa-d e $1 \mathrm{~m}$. White flowers July; very ornamental foliage; branches spreading and drooping. SYMPHORICARPUS, Indian Currant-d e $\mathrm{i} k \mathrm{n} \mathrm{p}$. Pink flowers in July; red colored fruit; graceful slender branches. SYMPHORICARPUS, Snowberry- $\mathrm{d} e \mathrm{k} \mathrm{n}$ o. Pink flowers July; showy, waxy white berries in autumn; very effective.

\section{Hardy Shrubs, Four to Six Feet}

AZALEA, Ghent-b d i $\mathrm{m} \mathrm{n}$ o. Great trusses of large flowers in many shades in May and. June; several varieties. AZALEA, Mollis or Sinensi-b d i $\mathrm{m} \mathrm{n}$ o. Flowers in shades of red, yellow, white and orange, blooming in May and June. BOXWOOD-See "Buxus, Box Tree" listed under broad leaved evergreens for a detailed description of this shrub. BUDDLEIA, Butterfly Bush-d i e m. Lilac-like flowers in July to September; very ornamental; recent introduction. CALYCANTHUS, Carolina Allspice- e i k n o. Aromatic shrub, deliciously fragrant chocolate flowers through summer. CEPHALANTHUS, Occidentalis, Button Bush-b $\mathrm{j} \mathrm{k} \mathrm{n}$. Dense globular heads of very attractive white flowers in July. CLETHRA, Virginica, Sweet Pepper Bush-d e b k o. Flowers in fragrant spikes, July; very ornamental and desirable. 


\section{Hardy Shrubs Four to Six Feet-Continued.}

CYDONIA, Japanica, Quince c d e i k. Large masses of scarlet flowers in May; fragrant and edible fruits; good foliage. KERRIA, Japanica, Globe Flower- $d e \mathrm{k} \mathrm{m}$. Bright yellow flowers in June; dense foliage with showy vivid green bark. PAILADELPHOS, Aureus, Golden Mock Orange-c d e i k. White flowers in May and June; brilliant yellow foliage. PHILADELPHUS, Lemoine's Erect Syringa-c d e i k. Sweet scented white flowers blooming in June; slender branches. PRIVET, h., Ibota-c k. 5-6-ft. White flowers in June; a low, dense shrub with especially attractive fruit; very popular. PRUNUS, Communis, Almond, Double White-d e i k. Showy white, double rose-like flowers in May: very attractive. PRUNUS, Communis, Almond, Double Pink- $\mathrm{d}$ e i k. Attractive rose colored flowers in May; blooms before leaves appear. RHODOTYPOS, K., White Kerria-d e k. Single white flowers in May followed by conspicuous black fruits; bright foliage. RHODODENDRONS-See "Rhododendrons"' under Broad Leaved Evergreens for a detailed deseription of this shrub. RIBES, Aureum, Golden Currant-e k. Fragrant yellow flowers in May; has dark brown edible fruit; foliage is glossy. RIBES, G., Pink Flowered Cur:ant-e k. Large purple rose flowers blooming in May; blue-black fruit; deep green leaves. RIBES, S., Red Flowered Currant-e k. Purple-red flowers blooming in May; has red bark twigs; the fruit is blue-black. ROBINIA, H., Rose or Moss Acacia - $f \mathrm{~g} \mathrm{p} \mathrm{k.} \mathrm{Rose} \mathrm{flowers,} \mathrm{May-June;} \mathrm{spreads} \mathrm{from} \mathrm{roots} \mathrm{like} \mathrm{raspberry;} \mathrm{hairy} \mathrm{branches.}$ SPIREA, Billardii-c d e i k. Dense panicles of rich pink flowers blooming in July and August; narrow, dense shrub. SPIREA, Billardii alba-c d e i k. Very similar to the above variety excepting the flower-blossoms which are snow-white. SPIREA, Van Houttei-c d e i k. Grandest of all the Spireas; resembles a fountain when white blooms appear in May-June. TAMARIX, Odessana (Caspian) - $\mathrm{d} b$ e $j \mathrm{~m}$. Lavender-pink flowers in July; fleathered, silver green foliage; bushy growth. WEIGELIA, Florida (Rosea)-e i m. An abundance of pink flowers in June; good foliage; an old garden favorite. VIEIGELIA, Florida Variegata - e i m. Rose flowers in June; leaves are margined with white; shrub is dense in growth. WEIGELIA, Hybrida Candida-e i m. Profusion of pure white flowers blooming in June; the plant is bushy in growth. WEIGELIA, Hybrida Desboisii- e i m. Trumpet-shaped, dark rose flowers blooming in June-July; spreading branches. WEIGELIA, Hybrida Eva Rathke-e i m. Handsome, fragrant, crimson flowers in June and July; most distinct variety. WEIGELIA, Hybrida IIendersoni-e i m. This variety has dark rose flowers and blooms in June and July; attractive. WEIGELIA, Fybrida Van Houttei-e i m. Clear carmine flowers, with orange markings in throat, blooming in June-July.

\section{Hardy Shrubs, Six to Eight Feet}

ARONIA, Arbutifolia, Chokeberry- $d e \mathrm{k}$. White flowers in May; foliage turns vivid crimson.in autumn; showy red fruit. AESCULUS, Dwarf Horse Chestnut-d e m. Upright panicles of showy white flowers in June; rare; broad spreading shrub. CORYLUS, A., Purple Fibert-d i m. Leaves remain deep purple all summer; good for contrast; useful for its fruit. DEUTZIA, Double White- $\mathrm{d}$ e i m. Panicles of sweet scented double white flowers in June; attractive upright growth. DEUTZIA, Double Pink-d e i m. Form similar to the above but with fragrant rose colored flowers blooming in June. DEUTZIA, Pride of Rochester-d e i l. Very large double white flowers in May; a very distinct and valuable variety. ELAEAGNUS, Longpipes, Silver Thorn (Oleaster) - d e i k n. Fragrant yellow flowers in April and May; red edible fruits. 


\section{Hardy Shrubs Six to Eight Feet-Continued.}

EUONYMOUS, Americus, Strawberry Bush-d e i k. Yellow-red flowers in June; good foliage; fruits very showy in fall. EUONYMOUS, Calatus, Winged Burning Bush-d e i k. Yellow-red flowers, June; gorgeous fall color; ornamental berries. HYDRANGEA, Aboresence, Hills of Snow-d e i k. Plant is covered with abundance of large white flowers in June-July. HYDRANGEA, Paniculata Grandiflora, Hardy-d e i k. Immense white flowers in September-October; also in tree form. IILAC, Alphonse Lavalle (Hybrid) - d e i k. Light blue, violet shaded flowers, double in May; a very popular shrub. IILAC, Chas. X. (Hybrid) - d e i k. Fine deep red single flowers in May borne in large trusses; a profuse bloomer. LILAC, Emile Demoine (Hybrid)-d e i k. Large double rose-pink flowers blooming in May; a very beautiful shrub. IILAC, Frau Bertha Dammann (Hybrid)-Large pure white flowers blooming in May in large trusses; attractive variety. LILAC, Ludwig Spath (Hybrid) - d e i k. This variety has single, dark purple colored flowers that bloom in May. LILAC, Mme. Lemoine (Hybrid) - d e i k. The blooms are double and of a beautiful pure white appearing in May. LILAC, Pres. Grevy (Hybrid) - d e i k. Shrub is covered with a profusion of beautiful large rose-lilac flowers in May. IILAC, Persian-d e i k. Pale lilac flowers in May and June in rather small and loose panicles; the leaves are small. IILAC, Villosa Himalayan-d e i k. Pink-lilac flowers in May and June; stout upright branches; has dull green leaves. IILAC, White Persian-d e i k. White flowers in May and June; form of above; very attractive among other shrubs. IONICERA, Fragrantissima Bush Honeysuckle-c d e m. Fragrant pink flowers, April-May; attractive, recurving branches. LONICERA, Morrowi, Japanese Bush IIoneysuckle-c d e m. White flowers freely produced, Miay-June; bright berries. IONICERA, Tatarica, Martarian Honeysuckle-c d e m. Abundance of fragrant pink white flowers May-June; red fruit. PRIVET, Amoor River- $\mathrm{c} \mathrm{h} \mathrm{m}$. 6-10-ft. White flowers in June and July; can be made very dense by frequent pruning. PRIVET, California- $\mathrm{ch} \mathrm{k} \mathrm{m}$. 6-10-ft. White flowers in June-July; darl: green; will stand any amount of pruning. PRIVET, Common-c k. 6-10-ft. White; June-July; narrow dull green foliage; attractive berries throughout the winter. PRIVET, Polish-c h k. 6-10-ft. White; June-July; leaves bluish-green and lustrous; half evergreen; hardiest privet. SAMiBUSCUS, Can. $\Lambda$., American Elder-d b e g k. Droad panicles white flowers, fragrant, June; black fruit; very showy. SAMBUSCUS, Lacintta, Cut-leaved Eidcr-d b e g k. Handsome cymes of fragrant white flowers, June-July; cut foliage. SAMBUSCUS, Nigra, Colden Leaved Elder-d b e g k. White flowers in July with bright yellow foliage; very attractive. SPIREA, Douglassi-c d e i k p. Beautiful deep rose colored flowers in July-August; young branches red-brown color. SPIREA, Prunifola fl. pl. (Bridal Wreath) - c d e i k. Very double, showy, pure white flowers; has excellent foliage. VIBURNUM, Deutatum (Arrow Wood) - d e $\mathrm{k} n$. White flowers in small flat heads, May-June; upright in growth. VIBURNOM, Plicatum (Japan Snowball) - d e i m. White flowers in June; a fine shrub with very beautiful foliage. VIBURNUI, Sterile (Common Snowball) - d e i k. White, globose flower clusters, May-June; attractive when in bloom. VIBURNOM, Tomentosum (Single-flowered Snowball)-d e im. Pure white flowers blooming in June followed by berries.

\section{Hardy Shrubs, Over Eight Feet}

AMORPHA, Fruticosa, False Indigo-d e $\mathrm{g} \mathrm{k} \mathrm{n.} \mathrm{Large} \mathrm{spikes} \mathrm{of} \mathrm{pea-shaped} \mathrm{violet-purple} \mathrm{flowers} \mathrm{in} \mathrm{June;} \mathrm{ornamental.}$ BENZOIN, Aes., Spice Bush-b d g i k. Handsome yellow flowers in April; conspicuous scarlet fruit; aromatic foliage. CARAGANA, Aborescens, Siberian Pea Shrub-e k. Pretty pea-shaped yellow flowers in May and Juna; showy dwarf treo. 


\section{Hardy Shrubs Over Eight Feet-Continued.}

CHIONANTHUS, White Fringe-See "White Fringe" under Deciduous Trees for a detailed description of this plant. COLUTEA, Arborescens, Bladder Senna-e m n. Pea-shaped red-yellow flowers in July; attractive Acacia like foliage. CORNUS, Sanguinea, Euronean Red Osier-b e k. White flowers in June; blood red bark in winter; berries black; upright. CORNUS, Stolonifera, Red Oiser Cornel-b e k. White flowers, berries white; bark is blood red; spreading in growth. CORNUS, Alba, Siberian Red Osier-b e k. Cream colored flowers blooming in June; bright red twigs, light blue fruits. CORNUS, Sericea, Silky Dogwood-b e k. White flowers in June; clusters of pale blue fruits; bark grayish-purple color. CORNUS, Alba, Yellow-leaved Dogwood-b e k. Form of above; leaves are bordered with yellow; a very striking plant. ELAEAGNUS, Augustifolia, Russian Olive- $\mathrm{d}$ e $\mathrm{k}$ i $\mathrm{n}$. Small fragrant yellow flowers, June; yellow fruits; silvery foliage. EXOCHORDA, G. flora, Pearl Bush-d k. White racemes of flowers in May; a very handsome shrub when in bloom. FORSYTHIA, Intermedia, Drooping Golden Bell-d e i g k. Yellow flowers in April; used extensively for arches or trellises. FORSYTHIA, Suspensa, Fortune's Golden Bell-d e i k. Form of above but more upright; golden yellow flowers, April. FORSYTHIA, Intermedia, Hybrid Golden Bell-d e i k. Yellow flowers in April; has very floriferous lustrous leaves. HAMMELIS, Virginiana, Witch Hazel-b d e k o. Fringe-like flowers blooming in September after leaves fall; good foliage. HIBISCUS, Syriacus, Aithea, Rose of Sharon-c h i m. Single and double flowers in August and Sept.; stands clipping. HIBISCUS, Syriacus, Variegated Althea-c d h i m. Double deep blue flowers in Aug.-Sept.; leaves marked yellow. KAIMIA, Latifolia, Mountain Laurel or Calico Bush-d b e g i k. See "Kalmia" under head Broad Leaved Evergreens. IILAC, Common-c d e i k. Deliciously fragrant purple flowers blooming in May; attractive bright green foliage. IILAC, Common White-c d e i k. Very similar to the above variety excepting the flowers which are pure white; May. IILAC, Josikea, Hungarian-c d e i k. Violet flowers borne in long, narrow clusters in June; leaves broad, long, pointed. PHILADELPHUS, Coronarius, Garland Syringa-c d e i k. Sweet scented white flowers in May and June; fine old form. PHILADELPHUS, Gordon's Syringa-c d e i k. Showy scentless white flowers in June and July; shrub of bushy growth. PHILADELPHUS, Grandiflorus, Large Flowered Mock Orange-d e i k. Large white flowers are slightly fragrant in June. RHAMNUS, Catharticus, Common Buckthorn-c k. Dull green foliage turning to yellow in autumn when berries appear. RHUS, Glabra, Smooth Sumac-d e i k p. Flowers in July; crimson fruit clusters; very beautiful autumnal coloring. RHOS, Typhina, Stag-horn Sumac-d e i k p. Similar to the above Smooth Sumac, but witk velvety hairy bark; July. SPIREA, Oqulifolia (Nine Bark)—c d e i k. White flowers blooming in June; branches are spreading; a strong grower. SPIREA, Oqulifola Aurea (Golden Spirea) - c d e i k. Variety of above with bright yellow foliage; flowers in June. STAPHYLEA, Colchica, Bladder-nut-d e b $\mathrm{m} n$ o. White flowers in May-June; attractive capsule fruit in fall; upright. TAMARIX, Gallica, Common Tamarisk- $\mathrm{d}$ b j m. White or pink flowers in April-May; blue-green foliage; dark bark. VIBURNUM, Lantana (Wayfaring Tree)- $d$ e $\mathrm{i} k$. White flowers in May or June; has decorative bright scarlet fruit. VIBURNOM, Opulus (High Cranberry Bush) - $\mathrm{d}$ e i $\mathrm{k}$. White flowers in May-June; decorative bright scarlet fruit. WETGELTA. Hybrida Candida-e $\mathrm{i} \mathrm{m}$. Profusion of pure white flowers blooming in June; shrub is bushy in its growth. 


\section{ROSES}

(H P)-Hybrid Perpetual. Vigorous, hardy; flowering in June and November; requires less care and attention than other classes. (H T) - Hybrid Teas. More vigorous grower; free flowering all summer; fine colors. (T)-Tea or Everblooming. Less vigorous, more tender; finest of flowers. (Poly.)-Polyantha. Fine class of climbing or pillar roses. (Noi.)Noisette. Rather tender; flowers usually in clusters. (Rug.)-Rugosa; Japanese variety. (Aust. B.)-Austrian Brier. (a)-Roses for porches, posts, archways, arbors, trellises, pergolas, summer houses, fences, etc.; (b)-For cemeteries, stone walls, banks and rockeries; (c)-For cutting or forcing, or indoor winter bloom (kind planted by professional florists); (d) -For hedges. (B C)-Bourbon and China. (Wich.)-Wichuraiana. (M)-Moss. (H C)-Hardy Climber.

ALFRED COLOMB-H P, C. Bright, rich crimson, dark flowers; plant is strong and erect, and a hardy grower. AMERICAN BEAUTY-H P, c. Rosy crimson color, large; best under glass; very popular variety among rose-lovers. ANNA DE DIESBACH-H P, c. Brilliant carmine rose; hardy and good;; blooms continually from June to November. BARON DE BONSTETTIN-H P. Dark crimson colored flowers; large and full; hardy; blooms from June to November. BARONESS ROTHCHILD-H P, c. Beautiful, clear pink, large flowers; hardy; blooms June to November; attractive. BON SIIENE-T, c. Deep rose color; fine buds; an old and favorite variety which blooms throughout the summer. BRIDE, THE-T, c. Beautiful delicate ivory white, sometimes being slightly blushed; blooms all summer; popular rose. BRIDESMAID, 'T, e. A free flowering rose that blooms throughout the summer;; flowers are a clear, bright pink. CAPT. HAYWARD-H P. Flowers crimson-carmine color and very fragrant; large, perfect form; hardy; free bloomer. CECIL BRUNNER-Poly, d. Baby rose, blush white flushed; a very popular dainty and pretty rose; blooms all summer. CLIO-H P. Flesh colored with deeper shaded center; vigorus and hardy; blooms continuously from June to November. CLOTHILDE SOUPERT-Poly, d. Creamy white color with a touch of pink at center; large, attractive, double, fragrant. COQUETTE DES ALPS-H P. White tinged with pale rose; free bloomer, very dainty; blooms from June to November. BLUMENSCHMIDT-T. Pure citron-yellow color with the outer petals edged with rose; very beautiful and popular rose. DEAN HOLE-H T, c. Flowers of a silvery carmine color shaded with salmon; a very handsome and distinct variety. ETOILE DE FRANCE-H T. Full flowers of a dark, velvety-crimson color; a very fragrant and attractive variety of rose. ETOILE DE LYON-T. Bright sulphur-yellow color and of a large and desirable size; full and free; very pretty. FRAU KARI DRUSCHKI-H P, c. The best pure white rose grown; large, full and free; blooms from June to November. GEN. JACQUEMINOT-H P. Glowing scarlet-crimson; an old red favorite with lovers of roses; June to November. GLOIRE LYONNAISE-H T. Pale lemon-yellow colored, tinted with white; floriferous; blooms from June to November. GRUSS AN TEPLITZ-T. c. Richest velvety crimson-scarlet; free flowering and a good rose for all purposes; June-Nov. HARRISON'S YELLOW-Aust, B. Semi-double flowers of a bright, clear, golden-yellow color; hardy and profuse bloomer. HELEN GOULD-H T. Rich, solid, bright pink and of a good size; a constant bloomer throughout the flowering season. HERMOSA-B C. Clear bright pink, fragrant, hardy; one of the best roses now in cultivation for general purposes. HOGH DICKSON-H T. Brilliant crimson-scarlet color; undoubtedly the best red rose that is grown at the present time. J. B. CLARK-H T. A full, deep scarlet rose with blackish-crimson center; a most unique rose and very highly prized. JONKHEER J. L. MOCK-H T. Carmine pink, improved Testout; perfect formation and highly perfumed; strong grower. JUBILEE-H P, c. Flowers are bright flashing red shaded to deep crimson; form is perfect; a very beautiful rose. 


\section{Roses-Continued.}

KAISERIN AUGUSTA VICTORIA-H T, c. Flowers are white and tinted with yellow; free flowering and attractive. KILLARNEY-H T, c. Suffused pale pink; a free bloomer and fragrant; blooms throughout the summer; very popular. KILARNEY, WHITE-H T, c. Wavy pure white, more double than the Pink Killarney; delightful fragrance; very hardy. LADY HILLINGTON-T, c. Orange yellow flowers; large, handsome buds; a very popular and good variety; fragrant. LA FRANCE-H T, c. Delicate silvery rose; fragrant and very popular; blooms continuously throughout the summer. LOUIS VAN HOUTTE-H P. Brilliant, vinous crimson; large and full; fine form; most vivid and distinct; attractive. MAD. CAROIINE TESTOUT-H T, d. Flowers are bright satiny pink color; handsome buds; full; blooms all summer. MAGNA CHARTA-H P. Extra large, bright rosy-pink; profuse bloomer; blooms from June to November; very hardy. MAMAN COCHET, PINK-T. Flowers of a rich coral pink, shaded with rosy crimson; enormous; blooms all summer. MAMAN COCHET, WHITE-T, c. This rose has large pure white flowers, tipped with pink in the fall; very hardy. MAMAN COCHET, RED (Mrs. B. R. Cant)-T, c. Flowers bright rose-red and extra large; vigorous; very hardy. MAMAN COCHET, YELLOW (Mlle. Helena Gambier)-T, c. A lovely canary-yellow with peachy-red center; attractive. MARIE VAN HOUTTE-T. Flowers are a canary-yellow tipped with light rose; blooms all summer; very hardy rose. MARSHALI P. WILDER-H P. Blooms are a deep, dark red; plant is vigorous and a free bloomer; June to November. METEOR-H T. Rich, velvety-crimson color, most vivid and striking; a great favorite among all lovers of roses. MRS. JOHN LAING-H P, c. Blooms are very fragrant, of a soft pink shade; large, full and of fine form; very hardy. MRS. R. G. S. CRAWFORD-H P. Flowers are rosy-pink, hardy and fine fragrance; good; blooms June to November. MY MARYLAND-H T, c. Salmon-pink colored flowers, said to surpass all others in its class; a very beautiful rose. PAPA GONTIER-T. Brilliant carmine color changing to rose; very popular and much sought after by admirers of roses. PAUL NEYRON-H P, c. Blooms are of enormous size. deep rose color; vigorous; plant is thornless and very hardy. PERIE DES JARDINS-T, c. Golden-yellow blooms; very fine shaped buds, large and full; blooms throughout summer. PERSIAN YELLOW-Aust, B. Blooms of a deep, golden-yellow color; double flowers; plant growth 3 to 4 feet; June. PRINCE DE BULGARIE-H T. Flowers are of a deep, rosy flesh tint, shaded with salmon; very vigorous and hardy. PRINCE DE B SIR THOS. IIPTON-Rug, d. A very fine double white rose; excellent for cut flowers; free bloomer; May and Sept. SOIEL D'OR-Aust, B. Large, globular flowers of a reddish-gold nasturtium color; bloom from June to November; hardy. SUNBURST-H T, c. Superb cadmium-yellow; bronze foliage; extra good specimen of the rose and very much admired. SUNRISE-T. Peachy-red colored flowers shaded with orange and crimson; good in the South; a very beautiful rose. ULRICH BRUNNER-H P. Large, cherry-red blooms; strong grower; floriferous, hardy; blooms from June to November.

\section{Climbing Roses Including the Rambler Group}

AMERICAN PILLAR-P, a b. Large, single pink flowers in clusters; extra good; blooms 3 to 4 inches across; hardy. AMERICAN BEAUTY-Cl, H P, a b. Deep pink to crimson, fragrant; very handsome and attractive when plant is in bloom. CLOTH OF GOLD-Noi, a. Flowers are large and double, and of a sulphur-yellow color; free flowering; standard variety. CLOTHILDE SOUPERT-Cl, T P, a. Rich, creamy-white blooms, sometimes blush; vigorous; very desirable variety. 
Climbing Roses, Including the Rambler Group-Continued.

CRIMSON RAMBLER-Poly, a b. Dark crimson-scarlet in clusters; this is the well-known and widely planted climber. DOROTHY PERKINS-Wich, a b. Double flowers in clusters and of a clear shell-pink color; very sweetly scented. EMPRESS OF CHINA-H C, a b. Rich red shaded to cherry pink; most satisfactory; flowers appear in large clusters. EXCELSA OR RED DOROTHY PERKINS-Wich, a b. Clear scarlet; a beautiful climbing rose and much admired. FLOWER OF FAIRFIELD-H C, a b. Sport from Crimson Rambler, everblooming; bright rich red; very beautiful. HIAWATHA-H C, a b. Brilliant scarlet, large clusters of single flowers; vigorous growth with bright green, glossy leaves. MARECHAL NEIL-T, a. Rich golden-yellow blooms, very beautiful; not so hardy as other varieties of the climbing roses. MARECHAL NEIL (Gardenia) - Wich, b. The finest hardy yellow climbing rose in cultivation and often prefered to others. MAD. CAROLINE TESTOUT-Cl, H T. Clear pink edged with silvery rose; extra large; a beautiful everblooming rose. MEMORIAL-Wich, b. Single pure satiny white; a very hardy grower and universally admired by all flower lovers. METEOR-Cl, H T, a. Exquisitely shaped, Jasqueminot colored red; called by some the superfine everblooming rose. PRAIRIE QUEEN-H C, a b. Bright rosy red, always very popular and considered the standby; extremely hardy. TAUSENDSCHON (Thousand Beauty)-Poly, a b. Large clusters of soft pink flowers; very beautiful and attractive. TENNESSE BELLE-H C, a b. Bright rose color; large and double; floriferous and hardy; free bloomer; desirable. VEILCHENBLAU (Blue Rose)-H C, a b. Rosy lilac when opening, changing to metallic blue; has very startling effect. WHITE DOROTHY-Wich, a b. Pure white sport of Dorothy Perkins; extra good, best of all the white climbing roses.

\section{Miscellaneous Roses}

BABY RAMBLER-D Poly, d. Clusters of deep, rich crimson throughout the summer; blooms completely cover the plant. BABY DOROTHY-D. Poly, d. Beautiful bright pink; fragrant and lasting; blooms continuously throughout the summer. CRESTED MOSS-M. Pink color; a beautifully mossed rose; growth 3 to 4 feet; blooms in June; a very good rose. GLORY OF THE MOSSES-M. Blush color, large and full; one of the best moss roses in cultivation and greatly admired. ROSA RUGOSA ALBA-Rug, d. Single white flowers; a good Rugosa; flowers freely throughout season; for bouquets. ROSA RUGOSA RUBRA-Rug, d. Single flowers of crimson color; good, hardy form; sturdy, disease-resisting bush. TREE ROSES-Different varieties are cultivated in this form and are used with good effect in landscape gardening. WHITE BABY RAMBLER-D. Poly, d. Clusters of deep creamy white throughout summer; grows to a height of 20 in.

\section{VINES}

(a) - For porches, fences, trellises or arbors; (b) - For large arbors and pergolas where large growth is needed; (c) - For rough walls and garden walls; (e)-For ground work on banks; ( $)$-For tree trunks; (g) - For carpeting under trees; (d) - For walls.

\section{Vines Recommended for Porches, Fences, Arbors and Pergolas}

ACTINIDA (Polygama) - a b f. 20-ft. Flowers white in July followed by yellow berries; a very useful and popular vine. ARISTOLOCIA, Dutchman's Pipe-b f. 30-ft. Flowers are purplish color; leaves are very large and heart-shaped. BIGONIA, Cross Vine-a b c f. 20-30-ft. An evergreen vine with orange colored flowers in July; very popular vine. 
Vines Recommended for Porches, Fences, Arbors and Pergolas-Continued.

BIGONIA, Trumpet Vine-a b f. 15-20-ft. Beautiful scarlet flowers blooming in July; leaves light green; very robust. BIGONIA, Scarlet Trumpet Vine-a b c f. 15-20-ft. Dark red flowers blooming in July; coarse vine; blooms large. BITTERSWEET, American-a c f. 20-ft. Orange-yellow capsules cling to the vine throughout the winter months. BITTERSWEET, Japanese-a c-f. 20-ft. Yellow flowers blooming in June followed later by yellow colored seeds. CLEMATIS, Large Flowered-a. 8-10-ft. Hybrids in various colors of which Jackmanni is the most popular variety. CLEMATIS PANICULATA, Japanese Star-a b d e c. 20-ft. White flowers; finest and most popular variety of this vine. CLEMATIS, Sweet Clematis-a b. 10-15-ft. Flowers are white; vine is very handsome and requires a sunny position. CLEMATIS, Virgin's Bower-a b e f. 12-ft. Has pure white flowers in August and September; fruiting in clusters. GRAPE WILD, Crimson Glory Vine-a b f. 20-30-ft. Beautiful, makes dense shade; foliage turns scarlet in autumn. GRAPE WILD, Fox-b e f. 20-30-ft. Abundant foliage; has red-brown colored berries; a very desirable grapevine. GRAPE WILD, Frost-b f. 20-30-ft. Sweet scented green flowers followed by small black berries; an excellent vine. GRAPE WILD, Summer-b f. 20-30-ft. The leaves have a brown fuzz on the underside; the fruit is black when ripe. HONEYSUCKLE, Hall's-a b e. 10-15-ft. White to yellow flowers in August and September; semi-evergreen; fragrant. HONEYSUCKLE, Golden-a c e. 10-ft. Similar to the above form but has yellow netted leaves; very sweet scented. HONEYSUCKLE, Japanesc-a b c e. 10-15-ft. Fragrant white to yellow flowers blooming from June to late August. HONEYSUCKLE, Monthly Fragrant or Belgian-a b c e f. 10-15-ft. Red-yellow flowers blooming throughout the summer. HONEYSUCKLE, Trumpet or Coral-a b. 10-15-ft. One of the showiest varieties cultivated; scarlet flowers in June. KUDZU-a b f. 40.60-ft. Has purple flowers blooming in August; a remarkable grower; leaves are dark green and wooly. MOONSEED-a c f. 10-15-ft. Yellow flowers blooming in July followed by crescent shaped bluish-black colored fruit, SIIK VINE-a b e f. 15-ft. In July the vine is covered with a prefusion of pretty purple flowers; vine is coarse. WISTERIA, American-a b c f. 15-20-ft. Lilac flowers in June; flowers are four to five inches long when fully matured. WISTERIA, White American-a b c f. White flowering form of the preceding variety and also has large flowers. WISTERIA, Chinese-a b c f. 20-30-ft. Purple flowers in May; sometimes a foot long; very beautiful and showy vine. WISTERIA, White - a b c f. 20-30-ft. The same as the above variety except the flowers are white and somewhat larger. WISTERIA, Double Flowered-a b c f. Very similar to the above form but with very double purple flowers; attractive. WISTERIA, Large Flowering Chinese-a b c f. 20-30-ft. Best of Wisterias; has deep blue or purple flowers in May.

\section{Vines Recommended for Walls of Buildings or Gardens}

AMPELOPSIS, Boston IFy-c d. 30-40-ft. One of the most beautiful and popular vines in cultivation; blue berries. AMPELOPSIS, Climbing Woodbine-a b c d f. 20-30-ft. Form of the Virginia Creeper but has stronger tendril discs. AMPELOPSIS, Englemanni IVy-c d. 20-30-ft. Similar to above variety but with a smaller and denser foliage; popular. AMPELOPSIS, Virginia Creeper-a b c f. 20-30-ft. Handsome and graceful; blue berries; beautiful leaves in autumn. EVERGREEN IVY, Japanese (Climbing Euonymous) - $\mathrm{c} d \mathrm{e} f \mathrm{~g}$. 10-15-ft. One of the finest evergreen vines; pink fruits. EVERGREFN IVY, Variegated Japanese (Variegated Euonymous) - c d e f g. 10-15-ft. Leaves edged with creamy white. IVY, English—c d e $f \mathrm{~g}$. 10-30-ft. Numerous forms cultivated; green and variegated leaved forms; evergreen; hardy. 


\section{HARDY PERENNIALS}

(a) - Hardy perennials for massing; (b)-For the border; (c)-For the rock garden; (d) - For the bog garden or wet places; (e)-For cut flowers; (f)-For ground covers; (g)-For shady locations; (h) -For sunny locations; (i)-Thrives in any good soil; $(j)$-Very hardy; $(k)$-Requires protection until well established; (1)-Specimens.

\section{Hardy Perennials Under One Foot}

ALYSSUM, Goldentuft-b i j. 1-ft. Yellow, April; folliage velvety gray; flowers fragrant in small clusters; easy culture. ARABIS, Rock Cress-b c i j. 6-in. White, April-May; flowers fragrant, showy, star-shaped, in masses covering jlant. CAMPANULA, Harebell-b k. 6-12-in. Blue or white; al summer; charming little plant growing in dense tufts. CERASTIUM, Snow-in-Summer-b c $f \mathrm{i}$. 6-in. White, June; numerus small flowers completely covering the plant. CONVALLARIA, Lily-of-the-Valley-a e g j. 6-in. White, May; prefers a deep, rich soli; does well in a shady location. DIANTHUS, Hardy Garden Pinks-b c $\theta$ i j. 6-8-in. Various; blooms May and June; fragrant flowers with fringed petals. IBERIS, Hardy Candy Tuft-b c i j. 6-in. White, May and June; foliage dark green; flowers in pretty clusters. RANUNCULUS, Creeping Buttercup-b c e $f$ i j. 8-in. Golden yellow in June-August; deep green divided foliage.

\section{Hardy Perennials, One to Two Feet}

ACHILLEA, Boule de Niege, Ball of Snow-b e i j. 18-in. White blooms all summer; pretty full bell-shaped flowers. ACHLlLEA, Pearl (Double White Yarrow) -b e i j. 15-in. White double blooms from July to September; good foliage. AQUILEGIA, Columbine, American-b c e g h i j. 1-2-ft. Scarlet and yellow blooms May.June; very free bloomer. AQUILEGIA, Columbine, Rocky Mt.-b $\mathrm{c} \theta \mathrm{g} \mathrm{h}$ i j. 12-18-in. Violet and white; April-July; very distinct and attractive. CHRYSANTHEMUM, Hardy Pompon-a b e. 1-2-ft. Various, September and November; flowers vary in size and shape. COREOPSIS, Tickseed-a b e i j. 1-2-ft. Yellow, all summer; rich green foliage; very good when used with shrubs. DAISY, Shasta-a e j. 1-2-ft. White flowers blooming from June to September; creation of Burbank; free flowering. DIANTHUS, Sweet William-b e i j l. 1 1/2-ft. Various, blooming in June and July; flowers in large, flat clusters. DICENTRA, Bleeding Heart-b e $\mathrm{i} j \mathrm{l}$. 2-ft. Rose, May and July; heart-shaped flowers on gracefully drooping stems. FUNKIA, Day Lily-b d e i j l. 1 1/2-ft. White; August-September; large spikes of fragrant flowers; leaves very large. GAILLARDIA, Blanket Flower-b e $\mathrm{i} j \mathrm{j}$. 1 1 1/2-2-ft. Yellow to red all summer; daisy-like flowers in various shades of yellow IRIS, German (Liberty) - $\mathrm{a} b \theta j$. 1-2-ft. Various colored flowers May to July; of easy culture; very showy flowers. IFCHNIS, Maltese Cross-a b c e i j. 2-ft. Scarlet blooms in June and July; foliage is narrow and hairy; attractive. MYOSOTIS, For-get-me-nots-c de k. 1-ft. Light blue flowers in May and June; familiar flower in very many gardens. PAPAVER, Oriental Poppy-a i l j. 2-ft. Scarlet blooms in June and July; robust and very decorative foliage; effective. PHYSOSTEGIA, False Dragon Head-a b e j. 2-ft. Rose-purple, July-Aug.; erect, bushy plants with very showy flowers. PLATrCODON, Balloon Flower-a b e i j. 2-ft. Deep blue flowers blooming July-August; a very showy perennial. PYRETHRUM or Chrysanthemum, hardy Feverfew-a b e i j. 11/2-ft. Various colored; June and July; very pretty flower. SCABIOSA, Mourning Bride or Cushion Flowers-b e i k. 1-1 1/2-ft. Light blue flowers June to August; free flowering. STOKESIA, Stoke's Aster-b e k. 1 1/2-ft. Light blue blooms all summer; aster-like flowers about three inches across. 


\section{Hardy Perennials, Two to Three Feet}

ANTHEMIS, Chamomile or Golden Marguerite-b e i. 2-3-ft. Yellow blooms June-August; profuse bloomer; very showy. CAMPANULA, Canterbury Bells-a b e k l. 2-3.ft. Shades of pink, purple and white flowers blooming in June and July. CAMPANULA, Cup and Saucer-a b e k l. 2-3-ft. White, rose and blue colored blooms; single cup-shaped flowers. CAMPANULA, Peach Bells-a b e k l. 2-3-ft. Dark violet colored blooms in June and July; flowers are cup-shaped. DELPHINIUM, Larkspur-b e c i j l. 2-3-ft. Flowers are blue and bloom in June and July; good for use among shrubs. DIGITALIS, Foxglove-a b e j. 2-3-ft. Varying from purple-pink to white; June and July; stately and handsome plant. HEMEROCALLIS, Yellow Day Lilies (Dumortierii) - b c e i j. 2-3-ft. Yellow blooms June to September; free flowering. IRIS, Japanese-a b d e k. 2-3-ft. Various colored; June to July; flowers are large; very beautiful everywhere planted. IRIS, Siberian Flag-a d b i j. 3-ft. Violet colored blooms in May and June; foliage is narrow and dense; very popular. IOBELIA, Cardinal Flower-b d e g j. 2-3-ft. Crimson flowers in August and September; a beautiful hardy plant. MONARDA, Bergamot or Oswego Tea-a b d e j. 2-3-ft. Bright red; June to September; a brilliant free flowering herb. PAEONIA, Officinalis (Common Peony) - a b e i j l. $2 \frac{1}{2}-\mathrm{ft}$. Crimson blooms in May and June; semi-double flowers. PAEONIA, Hybrid Particolored-a b e i j l. $2 \frac{1}{2}-\mathrm{ft}$. Rose and salmon colored flowers blooming in May and June; hardy. PAEONIA, Hybrid Pink-a b e i j l. $2 \frac{1}{2}-\mathrm{ft}$. Flowers bloom in May and June; pink in different varieties; attractive. PAEONIA, Hybrid Red-a b e i j l. $2 \frac{1}{2} \cdot \mathrm{ft}$. Red blooms in May and June, in different varieties; very handsome flowers. PAEONIA, Hybrid White-a b e i j l. $2 \frac{1}{2} \cdot \mathrm{ft}$. Pure white flowers appearing in May and June in various varieties. PAEONIA, Moutan (Tree Peony) - a b e i j l. 3-ft. Blooms of various colors in May and June; low branching shrub. PAEONIA, Tenuifolia (Fern Leaved)-a b e i j l. 11/2-ft. Deep crimson in May and June; finely cut foliage; attractive. PHLOX, Perennial-a b e i j. 2-3-ft. White, red, purple, pink and lilac colored flowers appearing from July to October. RUDBECKIA, Purple Cone Flower-b e i j. 2-3-ft. Purple flowers blooming in August and September; deep cut foliage. TRITOMA, Red Hot Poker-b e k. 3-ft. Vermilion-scarlet in August to October; drooping grass-like leaves; attractive. VERONICA, Speedwell-a b e i j. 2-3-ft. Deep blue; August and September; one of the best flowering perennials.

\section{Hardy Perennials, Three to Four Feet}

ACONITUM, Monkshood-b e g i j. 3-ft. Deep blue; Sept.-Nov.; bell-shaped flowers on long spikes; tuberous roots. ANCHUSA, Alkanet-b i j. 3-4-ft. Blooms from June to September; foliage is rough; flowers formed in small panicles. ANEMONE, Japanese Windflower-a b e i k l. 3-4-ft. Pink blooms appearing from September until frost; blooms freely. ANEMONE, Whirlwind-a b e i k l. 3-4-ft. Pretty semi-double white flowers; one of the hardiest plants in cultivation. AQUILEGIA, Columbine, Golden Spur-b $\mathrm{c}$ e g h i j. 3-4-ft. Golden-yellow blooms May to August; fragrant and showy. ASTERS, Michaelmas Daisy-a b e i j. 3-4-ft. Blue, white, purple, rose and crimson, with yellow center; September-Oct.

\section{Hardy Perennials Over Four Feet}

BOCCONIA, Plumed Poppy-a b i j. 5-8-ft. White blooms in August; good when used among shrubs; tropical in effect. BOLTONIA, False Chamomile-a b e i j. 5-ft. White; Sept.-Oct.; daisy-like flowers; excellent fall flowering perennial. BOLTONIA, Latisquama-a b e i j. 4-5-ft. Lavender; September-October; profuse bloomer and a valuable perennial. HELIANTHUS, Sun Flower-e h i j. 4-6-ft. Yellow, Julj-August; good among shrubs; light green, large, rough foliage. 
HIBISCUS, Meehan's Mallow Marvels-b d e i j. 6-8-ft. Shades of crimson, white and pink; blooms July to September. HIBISCUS, Rose Mallow-b d e j. 3-5-ft. White or rose; August and September; flowers large, tinged with purple. HOLLYHOCKS- a b k. 5-7-ft. Various colors in July; good among shrubs and in rows along garden walls or fences. IATHYRUS, Hardy Sweet Pea-c e $f \mathrm{i}$. 4-5-ft. Rose or white flowers from July to September; free flowering plant. LIATRIS, Blazing Star-a b e i j. 4-ft. Purple blooms in August and September; showy flowers in long spikes; pretty. RUDBECKIA, Goldeב Glow-b e i j. 5-7-ft. Golden yellow colored blooms July-September; flowers large, tinged purple. YUCCA, Filamentosa, Adam's Needle-a b e i j. 4-6-ft. Cream white blooms in June and July: half evergreen plant.

\section{BULBOUS AND TUBEROUS ROOTED PLANTS Hardy Bulbs for Spring Planting}

AMARYLLIS, Jacobean Lily-b i k. 2-ft. Velvety-crimson colored flowers blooming in July; a very pretty flower. BEGONIA-a b e i k. 1-ft. Various colored flowers appearing from July to August; bright and elegant flowers; attractive. CALADIUM, Elephant's Ear-h 1. 5-7-ft. Tropical in effect; prefers moist soil; extremely large heart-shaped leaves. CANNAS-a b l i. 3-7-ft. Various colors in the many hybrid forms; blooms throughout the summer; tropical foliage. DAHLIAS, Cactus-a b e i l. 2-4-ft. Various; long, narrow pointed, tubular and twisted petals; striking and attractive. DAHIIAS, Decorative-a b e i l. 2-4-ft. Various; large, full but opened faced; long, flat petals; gorgeous display. DAFLIAS, Double or Show-a b e i l. 2-4-ft. Various; most formal and perfect in shape; outlasts other types of dahlias. GLADIOLUS-a b e h i l. 2-5-ft. Shades of white, red, yellow and blue; July until frost; beautiful as an orchid. TUBEROSES-a b e i l. 2-3-ft. White; August; beautiful long, compact spikes of double flowers; very fragrant bloom.

\section{Hardy Bulbs for Autumn Planting}

CEIONODOXA, Glory of the Snow-a b c i j. 6-in. Blue; March and April; one of the earliest bloomers; very profuse. CROCUS, Spring-a b c g. 5-in. Various colors; April; of easy culture; colors all shades of blue, white, and yellow. GALANTriUS, Snow Drop-a b c g i l. 4-6-in. White blooms with green center; March or April; one of earliest. HYACINTHS, Summer (Candicans) - b e j k l. 3-ft. White; July to August; fragrant bell-shaped flowers in spikes. JONQUILS, or Campernella_ a b e i j. 8-10.in. Yellow blooms in April and May; very attractive and fragrant; popular. IIIIUM, Gold-banded Iily (Auratum) - $\mathrm{a} \mathrm{b} \mathrm{c} \mathrm{e} \mathrm{k.} \mathrm{3-ft.} \mathrm{White} \mathrm{with} \mathrm{yellow} \mathrm{bands} \mathrm{spotted} \mathrm{purple} \mathrm{from} \mathrm{July} \mathrm{to} \mathrm{August.}$ IIIIUM, Canadian Lily (Canadense) - $\mathrm{a} b \mathrm{c}$ e k. 2-3-ft. Deep orange or red spotted with brown from July to August. IIIIUM, Pardalinum-a b c e k. 2-3-ft. Scarlet, shading to rich yellow spotted with purple-brown; July to August. IILIUM, Trumpet or Easter Iily (Longiflorum)-a b c e k. $2 \frac{1 / 2}{\mathrm{ft}}$. White blooms July to August; not perfectly hardy. IIIIUM, Spotted Lily (Speciosum)-a b c e k. 3-ft. Pink-white spotted with red; Aug.-Sept.; desirable and hardy. IILIUM, Siberian Coral Lily (Tenuifolium)-a b c e k. 1-ft. Brilliant scarlet in June and July; foliage very fine. IIIIUM, Tiger Iily (Tigrinum) - a b e c k. 4.ft. Orange, July to August; very showy and common in old gardens. NARCISSUS, or Dafodils-a b e i j l. 6-8-in. April and May; yellow; blooms are very pretty and delicate; popular. TUITP-8 b $\theta$ i j l. 6-12-in. Various colors in April and May; single, double and parrot varieties; a very popular flower. 
\&
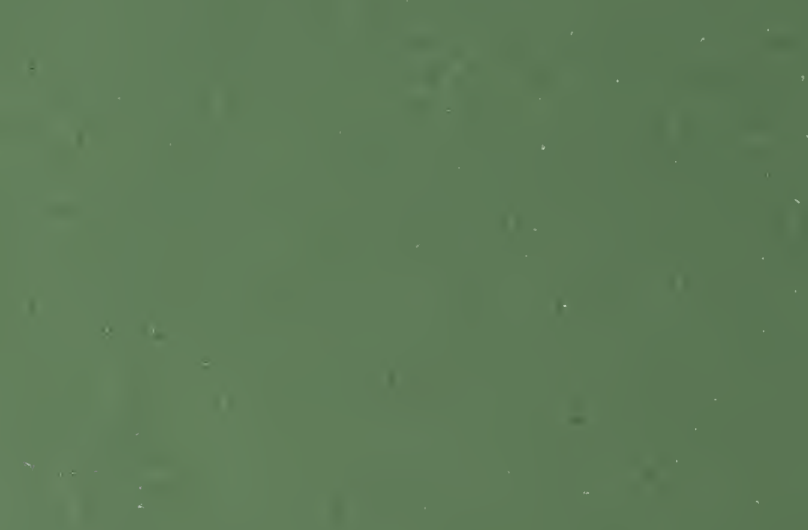